\title{
Claude Debussy, Géza Vilmos Zágon’s Pierrot lunaire, and the Question of Prosodic Accent ${ }^{1}$
}

\author{
Denis HeRLin \\ IReMus (CNRS-UMR 8223) \\ 2 rue de Louvois 75002 Paris, France \\ E-mail: denis.herlin@orange.fr
}

(Received: September 2018; accepted: October 2018)

\begin{abstract}
During a tour of Austria-Hungary in December 1910, Debussy met a young Hungarian Francophile composer, Géza Vilmos Zágon (1889-1918). The latter sent him the manuscript of the Pierrot lunaire, a cycle of six melodies from the collection of the Belgian poet Albert Giraud. Debussy reviews the vocal line, emphasizing that the corrections he has made almost all concern "prosodic accents." This rereading of a work by a young composer is a unique case for Debussy and testifies not only to his openness to young composers, but also to his interest in Giraud's poems, as André Schaeffner had so rightly anticipated in 1953 in his article "Variations Schoenberg." It also reveals Debussy's deep sensitivity to the French language verse and rhythm.
\end{abstract}

Keywords: Debussy, Zágon, Giraud, Schoenberg, Pierrot lunaire, song, prosodic accent

On 28 November 1910, Debussy left Paris and embarked upon a concert tour in the Austro-Hungarian Empire. As usual, he was hardly enthusiastic about having to make such a trip. And yet, on 7 December, he returned to the capital with many fond memories of his stay in Budapest and of the warm reception he had received there, as he indicated on that very day in a letter to Gusztáv Bárczy, one of the owners of the Rózsavölgyi publishing house and the man who had organized his tour:

1. I should like warmly to thank all of those who have assisted me in the preparation of this article: László Vikárius, who drew to my attention the existence of the manuscripts of Zágon; Boglárka Illyés, who generously shared with me her knowledge of Zágon's life and work; and, for various kindnesses, Nicolas Dufetel, Péter Bozó, Gergely Fazekas, Csilla Pethő-Vernet, Jean-Christophe Branger, Manuel Couvreur, and JeanPierre Smyers. Finally, I am very grateful to Françoise Massé and Anne Le Bozec for having given new life to Zágon's Pierrot lunaire during the colloquium Claude Debussy d'hier à aujourd'hui organized by l'Université Paul-Verlaine, in Metz, on 24-25 September 2018. 
Here I am back in Paris, which, despite the delights of Budapest, remains nonetheless a very charming town. Even though I'm exhausted, I want to tell you right away how deeply touched I was by your hospitality. It was exceedingly good of you to arrange matters in order that I be able to avoid the difficulties usually encountered by visitors to foreign countries who do not know the language ... I also left on the piano the score of Estampes, in which you will also find my Hommage à Rameau. Would you please be so kind as to return these things along with the popular Hungarian music you promised to send along, and which I am very anxious to have!! I believe that this represents just about everything that I left behind ...2

Indeed, on 5 December, in the concert hall of the Vigadó, a hall that resembled a "Turkish bath," ${ }^{3}$ as the composer put it, Debussy had played the Children's Corner, Pagodes, Hommage à Rameau, and Jardins sous la pluie, and he had accompanied Rose Féart in the first book of Fêtes galantes, in Green (the fifth of the Ariettes oubliées), and in two Proses lyriques (De soir and De fleurs). The Waldbauer-Kerpely Quartet also gave what Debussy described as an especially remarkable performance of his Quatuor.

Ten days later, on 19 December, Debussy again thanked Bárczy, this time for having sent to him the "Hungarian music," and added at the end of his letter:

I have also received the music of our friend Guillaume Zágon, which you may be sure I will attend to shortly. He is a very pleasant fellow and is full of promise! ${ }^{4}$

Until recently, it was not known which work Géza Vilmos Zágon had sent to Debussy, and in what sense Debussy was to "attend" to it. It was only at the time of the exhibition on "Géza Vilmos Zágon in Paris, 1912-1914," which ran at the National Széchényi Library of Budapest (H-Bn) from 26 March to 31 May 2013, that it became apparent, first, that the work in question was the autograph manuscript of Pierrot lunaire - Zágon's settings of six poems from the collection by Albert Giraud - and, second, that what Debussy was to attend to, as we know from the corrections in his hand, was the setting of the text in this composition for voice and piano. ${ }^{5}$ At the conclusion of the exhibition, Boglárka Illyés, curator of the National Széchényi Library, published an important article on the visit that Zágon made to Paris from 1912 to 1914: "The Parisian Ambassador of the New

2. Claude Debussy, Correspondance (1872-1918), ed. François Lesure and Denis Herlin (Paris: Gallimard, 2005), 1352.

3. Ibid., 1348-1349.

4. Ibid., 1361. The excerpt from the letter cited here includes a correction to the text of the Correspondance: "votre ami Zágon" should rather read "notre ami Zágon."

5. At the time of my visit to Budapest, in September 2016, I was able to verify that the changes in Zágon's manuscript are without a doubt in the hand of Claude Debussy. 
Hungarian Music, Géza Vilmos Zágon: His Career and Selected Correspondence." The autograph manuscript of Zágon's Pierrot lunaire is a truly unique document, for, to the best of our knowledge, there is no other such evidence of Debussy having revised the work of a younger contemporary. But before turning our attention to the revisions made by the composer of Pelléas et Mélisande, let us briefly to outline the promising career of Zágon, who died prematurely at the end of the First World War, at the age of 29, and to attempt to set out the reasons that led Debussy to review and revise the prosody of the six songs that comprise Pierrot lunaire - songs whose texts are well known, of course, from the melodrama by Arnold Schoenberg. (For his own Pierrot lunaire, the Austrian composer took over the texts from the German translations by Otto Eric Hartleben, which first appeared in 1893. $)^{7}$

It is all but impossible to find a biography of Géza Vilmos Zágon (Figure 1). He is almost nowhere to be found, not in the New Grove Dictionary, not in Die Musik in Geschichte und Gegenwart. The biographical elements that follow are taken from the above-mentioned article by Boglárka Illyés. Zágon belonged to the circle of composers around Béla Bartók and Zoltán Kodály, with both of whom he maintained a correspondence. He was born in Budapest, in 1889, under the name of Vilmos Zerkowitz, into a family of German-speaking Jewish shopkeepers. He changed his name to Zágon in 1909. After taking piano lessons with Henrik Gobbi, he studied composition from 1907 to 1909 at the Budapest Academy of Music, in his first year with Hans Koessler, in his second, with Viktor Herzfeld. In the spring of 1910, he travelled for the first time to Paris. ${ }^{8}$ In 1911, the Rózsavölgyi publishing house put out his "Opus 1," a triptych for piano entitled Poèmes with individual titles in French: "Idylle," "Dans[e] des faunes," and "Élégie." 9 The reviewer for the Revue musicale S.I.M. took note of them in the issue of December 1912, wondering aloud where such music might possibly come "from Hungary, if

6. Boglárka Illyés, "Az új magyar zene párizsi követe. Pályája és válogatott levelezése," Lymbus Magyarságtudományi Forrásközlemények 2014 (2015), 323-358; available online at: http://epa.oszk. hu/01500/01500/00011/pdf/EPA01500_lymbus_2014_323-358.pdf (last accessed: 20 September 2018). A French version of this text was published under the title "L'ambassadeur parisien de la nouvelle musique hongroise, Géza Vilmos Zágon. Sa carrière et sa correspondance choisie," in Studia Musicologica 58/2 (June 2017), 255-293. References that follow here are to that French publication. It should be noted that, in an Appendix, Boglárka Illyés transcribed a certain number of letters preserved in the collections of the Széchényi National Library and addressed to the young Hungarian composer, including one, heretofore unpublished, from Claude Debussy (see our Appendix 3); another from the critic Émile Vuillermoz; six from MichelDimitri Calvocoressi (the musicographer who was especially interested in the young Hungarian composer); two from Louis Laloy; and one from the Parisian publisher Albert Zunz Mathot.

7. See Christian Berg, “»Prête-moi ta plume...«Pierrot, de Giraud à Schönberg,” Modernité 16 (2002), 141, n. 27.

8. Boglárka Illyés cites a letter from Béla Bartók to Sándor Kovács in which he asks where he should send the songs "that Zágon had sent to him" (see "L'ambassadeur parisien," 258).

9. "POÈMES / I. IDYLLE / II. DANSE DES FAUNES / III. ÉLÉGIE / POUR LE PIANO / PAR / VILMOS GÉZA ZÁGON / OP. 1 / RÓZSAVÖLGYI \& C IE / BUDAPEST ET LEIPZIG / LE TITRE PAR LILI MIHÁLY.” "Idylle" is dedicated to his mother; "Danse des faunes" to Leó Weiner, and "Élégie" to Rudolph Ganz. 
Figure 1 Photograph of Géza Vilmos Zágon (Comœedia illustré, $5 / 17$ [5 June 1913], p. 830)

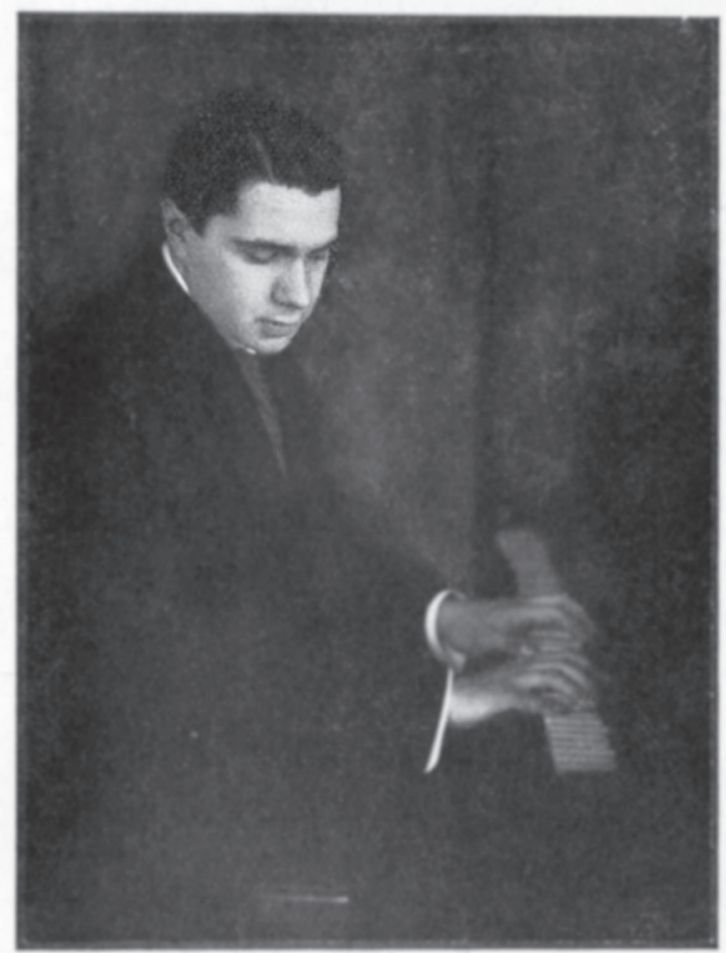

15. Zxcos.

I am to believe this astonishing vigor, and these cheekily bold structures and harmonies." ${ }^{10}$ Be this as it may, these Poèmes demonstrate both Zágon's evident Francophilia as well as his knowledge of French. ${ }^{11}$ It is no doubt for these reasons that he had determined to travel to Paris, where he remained from 1912 to 1914, thanks in part to a two-year fellowship he had received as the winner of the "Jubilee Prize of the Crowning of Franz-Joseph." ${ }^{2}$ In Paris, Zágon became an active participant of the musical life of the day, joining the brand new Société Musicale Indépendan-

10. V. P., "L'édition musicale," Revue musicale S.I.M. 8/12 (December 1912), 69.

11. It is striking to observe that in these poetic settings of Poèmes, Zágon sets down, along with the traditional Italian terms, certain indications in French: "Idylle" (2, Doux et tranquille / 3, toujours également mp chantez); "Danse des faunes" (5, Rapide et bien rhytmé [sic] and, in a footnote: *Les notes tirées en bas [sic] doivent être jouées toujours par la main gauche [The notes with downward stems are always to be played by the left hand] / 6, Un peu calmé, mais pourtant assez vite); "Élégie" (9 très lointain / 10, avec une passion étouffée; plus clair; augmentez peu à peu). Finally, next to the title "Élégie," Zágon cites as an epigraph page 9 of his verses written in French: "Elle s'en est allée, / Et jamais je ne l'aurai..."

12. See Boglárka Illyés, "L’ambassadeur parisien," 264. It is Illyés who suggests that this prize, founded by the Council of the City of Budapest, was similar to the celebrated French Prix de Rome. 
te, and giving there, on 22 May 1913, the first performance of his two-movement Sonata for Piano in D-flat Major. The critic for Le Monde musical found this work marked by "Debussysme"; 13 it was published by the Rózsavölgyi firm in 1914. ${ }^{14}$ A few months later, in the same society's concert series, Zágon gave the French première of his Pierrot lunaire, to which I shall return below. Finally, between January and March 1914, Zágon acted as pianist for the lecture series given by Michel-Dimitri Calvocoressi ${ }^{15}$ on the subject of contemporary music in Europe. According to the critic for the Revue musicale S.I.M., the pianist played "with all of the highly praiseworthy enthusiasm of the young Hungarian school to which he belongs," adding in particular that his playing of Bartók and Kodály was marked by "absolute understanding."16 As proof of Zágon's solid standing in France, we

13. P. M., “EEuvres de Zágon, Braïloï, Ladmirault, Le Quatuor de Binenbaum. SMI - 22 Mai,” Le Monde musical 25/10 (30 May 1913), 167: "Born in Hungary, M. Vilmos Zágon has been influenced by the graces of the modern French school; he seems uninterested in the colorful contemporary music of his own country. Imprinted with Debussysme, his Sonata for Piano, in the performance of which he has demonstrated his own remarkable skills as a pianist, nonetheless exhibits absolutely none of the typical banalities habitually put forth by the disciples of the great Claude-Achille. One continuous long line maintains the listener's interest. The author is a very fine and very elegant musician.” In L'Homme libre (26 May 1913), Alfredo Casella indicated that this Sonata had been "remarkably well played by the composer" before a "very large public." See Alfredo Casella, Gli anni di Parigi. Dai documenti, ed. Roberto Calabretto (Florence: Leo S. Olschki, 1997), 293.

14. "[Zágon's monogram] / VILMOS GÉZA / ZÁGON / SONATE / EN RÉ b / POUR PIANO / PRIX COUR 3.60 / Mk. 3.- NETTO. / DROITS D'EXÉCUTION RÉSERVÉS / PROPRIÉTÉ DES EDITEURS POUR TOUS PAYS. / RÓZSAVÖLGYI \& CEE. / EDITEURS DE MUSIQUE DE LA COUR / BUDAPEST ET LEIPZIG. / COPYRIGHT 1914 BY RÓZSAVÖLGYI \& $C^{\circ}$. BUDAPEST-LEIPZIG." Of this work, dedicated "à mon cher maître Henri Gobbi en sincère homage" (the dedication is in French), two manuscripts have been preserved: H-Bn Ms. Mus. 2.017 (from the papers of Zágon); and Ms. Mus. 5.135. Neither manuscript seems to preserve the original version of the work. In a letter to Béla Bartók dated 26 April 1913, Zágon specifies that he has composed an "entirely new second movement" (see Denijs Dille, "Briefe an Bartók," Documenta Bartókiana, ed. Dille [Mainz: Schott, 1965], 21, 23). Furthermore, as in his two other works, Zágon employs here a number of expressions in French, especially in the second movement: I (2, Andante très expressif / 2, footnote *Le signe [a square fermata] signifie un léger point d'arrêt moins important que le point d'orgue); II (6, Assez mouvementé; sans rigueur /7, marquez toujours la ligne mélodique; hésitez un peu; éclatant ; au mouvement / 8, diminuez peu à peu; très expressif et avec un accent libre; cédez un peu; au mouvement; très distinct; très expressif / 9, chanté et sans rigueur; au mouvement / 10, très expressif; avec beaucoup de chaleur; comme un doux et triste souvenir / 11, très expressif; avec une liberté d'expression imitant un récitatif; un peu au-dessous du mouvement; mp triste; retenez un peu; au mouvement; distinguez bien; distinguez beaucoup / 12, cédez et diminuez peu à peu; au mouvement; distinguez bien; distinguez beaucoup; très expressif comme la première fois; cédez un peu; au mouvement; très distinct; très expressif / 13, criez le thème désespéré / 14, retenez, au mouvement; comme un souffle de vent; retenez, au mouvement; ralentissez / 15, marquez bien le thème; sans retard; très expressif; reprenez le mouvement; un peu largament [sic]; cédez peu à peu; retenu; comme une fanfare; sans vitesse; laissez vibrer).

15. Calvocoressi had taken note of his talent, after hearing the Sonate pour piano at the S.M.I. in May 1913, in an article published in Comøedia illustré (5/17 [5 June 1913], 830) that included photograph of Zágon (831) (Figure 1): "Likewise, I believe that one will be much interested in the Sonata by M. Zágon, especially the second movement, which is lovely in allure and highly expressive."

16. "Le piano," Revue musicale S.I.M. 10/3 (15 February 1914), 9. Michel Dimitri Calvocoressi had given a series of lectures entitled "Études d'Analyse musicale" on 16, 23, and 30 January, at the École des Hautes Études Sociales, 16, rue de la Sorbonne. As noted by the journalist for the Revue musicale S.I.M., it was in the course of these lectures that Zágon had played excerpts from the works of Bartók (notably from Pour les enfants and from the Danses roumaines, op. 8a), from the works of Kodály, and from his own compositions, notably from the Sonata in D-flat Major. These lectures, as Léon Vallas notes, were repeated in March: "The lectures of M. Calvocoressi, at the École des Hautes Études, devoted to contemporary music from abroad, were of considerable interest. Our subscribers will hear their main points in the lectures that my colleague [Calvo- 
also note that in 1913, the publisher Albert Zunz Mathot, who was the secretary of the Société Musicale Indépendante ${ }^{17}$ brought out Jeux de vagues,$^{18}$ a piece for piano solo that, as the Revue musicale S.I.M. pointed out, could not have carried a more Debussy-like title: here was something to be added "to the repertory of aquatic music," and "to the music of the school of Ravel."19

Not satisfied with being merely a fine pianist and a promising composer, Géza Vilmos Zágon became as well a quite remarkable music critic. ${ }^{20}$ Only a few days before Debussy's arrival in Hungary, the journal Zeneközlöny published, on 1 December 1910, a new issue entirely devoted to Debussy. ${ }^{21}$ As Gergely Fazekas emphasizes in an article on Debussy reception in Hungary, ${ }^{22}$ this journal was the house organ of the Rózsavölgyi publishers, who were of course responsible for Debussy's coming to Budapest in the first place. Along with a brief study of Pelléas et Mélisande from the pen of Emil Lichtenberg, ${ }^{23}$ the journal included four further articles, all by Zágon. The third is a thorough analysis of the Quatuor, ${ }^{24}$ which was performed on 5 December 1910; the fourth is a review of that concert. ${ }^{25}$

coressi] will give in Lyon on 26 February and in Paris on 7 and 14 March. They will also hear performances by some of the artists who brilliantly illustrated these highly substantive sessions: $\mathrm{M}^{\mathrm{me}}$ Nikitina, and MM. Casella, Ornstein, and Zágon (Revue française de musique, 12/9 [25 February 1914], 354-355). The lectures took place in the Salle Villiers, 64, rue du Rocher, on 7 and 14 March. In his review, Paul Ladmiraut commented on the musical excerpts: "The musical examples followed - numerous, and convincing - ... and concluded with unusual works by Bartók, Kodály, and Zágon, where the influence of Hungarian folklore is undeniable. One nonetheless notices in particular the deeply moving expression of the two last "Nénies" of M. Bartók, and the affecting musicality of M. Kodály" (Revue musicale S.I.M., 10/6 [15 March 1914], 8). See also the letters of Calvocoressi to Zágon cited by Boglárka Illyés, "L’ambassadeur parisien,” 290-292.

17. See Michel Duchesneau, L'Avant-garde musicale à Paris de 1871 à 1939 (Sprimont: Mardaga, 1997), 66.

18. "Vilmos Géza Zágon / [Zágon's monogram] / Jeux de vagues / 'Hullámjáték' / pour Piano 2 mains / Prix net 2.50 Frs. / ALLEMAGNE / BREITKOPF ET HÄRTEL-LEIPZIG / 36/38, NÜRNBERGER STRASSE / BELGIQUE / J. B. KATTO-BRUXELLES / 12 ET 14, RUE D’ARENBERG / EDITIONS LiTTÉRAIRES / ET MUSICALES / A. Z. MATHOT / 11, RUE BERGÈRE, PARIS." The first page of music is preceded by an excerpt from a poem by Émile Verhaeren, "Le port," selected from the collection Les Villes tentaculaires (Bruxelles: E. Deman, 1895). The tempo and expressive markings here are in French.

19. "La musique ravélienne." See V. P., "L'édition musicale," Revue musicale S.I.M. 9/23 (1 December 1913), 65 .

20. Among his critical writings, we find twelve essays on the sonatas of Beethoven ("Beethoven zongoraszonátái esztétikai megvilágításban”), published in the journal A Zene between February 1911 and February 1912, and a text entitled "Reflections on ancient and modern music" ("Gondolatok régi és új muzsikáról") which appeared in Zeneközlöny 9 (1911), 269-275. On his activity as a critic, see Boglárka Illyés, "L'ambassadeur parisien," 261-262.

21. Zeneközlöny 9/3 (1 December 1910), 74-96.

22. See Gergely Fazekas, "Musique »laide« et »malsaine« ou »boussole indiqu[ant] un art plus pur de qualité supérieure«? La réception de Debussy en Hongrie entre 1900 et 1918," Cahiers Debussy, 33 (2009), 42-46. This article also appeared in English: “»Unhealthy« and »Ugly« Music or »a Compass Pointing towards a Purer Art of Superior Quality«? The Early Reception of Debussy in Hungary (1900-1918)," Studia Musicologica 49/3-4 (September 2008), 321-339.

23. Emil Lichtenberg, "Debussy: Pelléas és Mélisande," Zeneközlöny 9/3 (1 December 1910), 88-91. As Fazekas demonstrates, Pelléas et Mélisande should have been represented at the Budapest Opera during the 1908-1909 season ("Musique »laide« et »malsaine«," 39). Finally, Debussy's lyric drama was going to be given for the first time on 26 November 1925.

24. Géza Vilmos Zágon, "Debussy: G moll vonósnégyes,” Zeneközlöny 9/3 (1 December 1910), 91-95.

25. Zágon, “Debussy müveiről,” Zeneközlöny 9/3 (1 December 1910), 81-87. 
The second article consists of a detailed description of the works of Debussy, ${ }^{26}$ opening with a first section devoted to the "Orchestral Works" from the Marche écossaise to the three Images for orchestra (of which, at that time, only Ibéria and Rondes de printemps had been performed and published in December 1910). The second section is devoted to the "Works for Piano," up to the first book of Préludes, which Durand had just recently published in April 1910. After a brief paragraph on "The Chamber Music," the article concludes with a section on the "Vocal Music" with a first part on works for "Voice and Piano" (which does not include the Trois Ballades de François Villon, published in September 1910) and a second part on works for voice and orchestra that includes L'Enfant prodigue and La Damoiselle élue, and concludes with the mention of the three dramas on which Debussy was at work at the time: the Histoire de Tristan (which, according to Zágon, it would be interesting to compare with the music drama by Wagner); and La Chute de la maison Usher and Le Diable au [sic] beffroi, based on the stories of Edgar Allan Poe, the latter two works said here to be intended for performance at the Metropolitan Opera of New York. This second article, then, provides ample evidence of Zágon's profound knowledge of almost all of Debussy's works. It is clear that he must have made a study of them during his first stay in Paris in the spring of 1910 .

The special issue of Zeneközlöny opened with a seven-page article entitled simply "Claude Debussy." ${ }^{27}$ As Gergely Fazekas emphasizes, this article represents a highly "penetrating interpretation of the art and aesthetics of Debussy." Indeed, Zágon's text of 1910 demonstrates a knowledge and understanding of the composer that go far beyond those of most of his contemporaries, with the exception of Paul Dukas. Expressing disdain for conservatism in art, and praise for the exceptional personality of Alfred Bruneau, Zágon traces the trajectory of Debussy's career with particular regard for the then current movements of impressionism and Japonism.

\begin{abstract}
All of Debussy's works are impregnated with an intense and all-encompassing atmosphere, out of which there develops - as though coming into view from behind a veil - a panoply of short motifs, splashes of color, sometimes chiseled, sometimes fluid, sometimes the combination of these two; only in exceptional cases can we speak of anything like thematic development in the traditional sense of the term. Atmosphere is the principal element of his music. ${ }^{28}$
\end{abstract}

26. Zágon, “Az előadásra kerülő zongoradarabok méltatása,” Zeneközlöny 9/3 (1 December 1910), 96. I am grateful to Csilla Pethö-Vernet for having generously provided me with a complete French translation of these texts by Zágon. That translation appears in the French publication of the present article. An English translation of Csilla Pethö-Vernet's French translation appears here, in Appendix 1.

27. Zágon, "Claude Debussy,” Zeneközlöny 9/3 (1 December 1910), 74-80. A complete translation of this text by Zágon, Csilla Pethö-Vernet, appears in the Appendix to the French publication of this article.

28. Zágon, "Claude Debussy," 76. 
Zágon then adeptly analyzes Debussy's use of titles, showing how these are by no means ends in themselves:

Debussy's aim, on the other hand, is never to make of his music the interpreter of some sort of program; he wishes simply to reflect and to communicate the impressions that are inherent in the program. ... Whatever the program might be that serves as the basis for his writing, the end result will always be a homogeneous ensemble of pure aesthetic abstraction, in which one will find throughout an acceptance of ineluctable choices, and a rejection of elements that are unimportant and superfluous. ${ }^{29}$

Furthermore, on the subject of the so-called lack of form that supposedly marked much of Debussy's output, the young Hungarian composer remarked:

Because of the impressionistic nature of his music, we rarely find in it structures in the traditional sense of the word. In his shortest pieces, we can detect two-part or three-part forms resulting from the recurrence of certain motifs or certain interdependent and analogous passages. It is furthermore admirable that, even in his most complex works, where no such articulations are present, the proportions are so perfect that the whole seems to be the result of an inner necessity, of a pure and absolute aesthetic principle. ${ }^{30}$

Zágon even proposes an astonishing comparison of Debussy and Picasso, proof that he had seen the works of the Spanish master in Paris at a time when they were far from enjoying the celebrity they have today.

To those who, even after hearing this explanation, still remain perplexed by the work of Debussy, I should like to propose an experiment: go and look at a painting by Picasso (not to be confused with Pissar[r]o). The angularity of his figures represents not a malformation but rather a kind of immobilization - an immobilization with the expressive value of a split second in time, a momentary reflection of an emotion, an emotion that is so inaccessible and so secreted that it cannot be revealed by mere externalized means. ... Most of the works by Debussy that seem mysterious are analogous to this artistic process ... 31 
Finally, with reference to Debussy's musical language properly speaking, Zágon suggests that his harmonic system is

entirely personal, it is different from everything else ... . Debussy does not take into account the rules of harmony, in the classical sense of the word. In his music, what is in control is a freedom that is absolute, a freedom, however, that is never provocative of disorder, a freedom that is always strictly governed by logic and aesthetics. Indeed, Debussy has created what one might wish officially to designate as the harmony of freedom. ${ }^{32}$

As for Debussy’s dissonance treatment, Zágon is quite precise:

dissonances never sound harsh to the ear; when they are resolved, their apparent severity serves only to heighten the warmth and sweetness of the resolution. What is more, Debussy sometimes uses dissonances as consonances; in his hands, dissonance becomes capable of suggesting closure and conclusion ... 33

Even if Debussy never read this text, he must have known something of its content through the intermediacy of Gusztáv Bárczy, who had presumably commissioned the articles for this special number of the journal. And he must have been touched by the young Hungarian composer's enthusiasm for and perceptive views of his music. It is surely for this reason, primarily, that he accepted to go through the six songs of Zágon's Pierrot lunaire and to offer to help him to correct the prosody, which, no matter how much of a Francophone and Francophile Zágon may have been, did need correction. It should also be added that Debussy himself knew and apparently esteemed the poetry of Albert Giraud: indeed, that he did not set some of it himself is a matter to which we shall return, indirectly, at the end of this study.

As we know from his indications on the autograph manuscript, Zágon worked on this cycle of six songs on Pierrot lunaire between October 1908 and September 1909, when he was still a student at the Budapest Academy of Music, and thus well before Arnold Schoenberg began work on his own melodrama, in 1912. The first question we need to ask is how Zágon came to know Albert Giraud's collection of poems. Did he first read them in the translation by Otto Erich Hartleben that had been published in Berlin in 1895? Perhaps. But he nonetheless determined to set them in the French version - not the version published in October 1884 by Lemerre, ${ }^{34}$ the publisher of the Parnassian poets and in particular of Verlaine's Fêtes

32. Ibid., 77.

33. Ibid., 77.

34. The official date of publication was June 1884. Nonetheless, in La Jeune Belgique (3/9-10 [15 August-15 October 1884], 488) we find an announcement of the publication for October: "Lemerre has just 
galantes, but rather the version published in 1898 by Fischbacher, under the title of Héros et Pierrots, a volume that includes two other cycles by Giraud, Les Dernières Fêtes and Pierrot narcisse. ${ }^{35}$ For this second edition, Albert Giraud not only removed mention of the Rondels bergamasques, which are found in the Lemerre edition, but also made a certain number of modifications to the remaining poems. (Two of the changes he made for the edition of 1898 appear in Zágon's settings.) ${ }^{36}$

"Albert Giraud" (1860-1912) is in fact the pseudonym of Albert Kayenbergh, a pianist, lawyer, journalist, and writer who published some ten collections of poetry that range from Pierrot lunaire of 1884 to the Concert dans le musée of 1921. Were it not for Schoenberg's celebrated composition, Giraud's name would by now surely have faded into total obscurity. He was an active contributor to $L a$ Jeune Belgique (1881-1897), a journal devoted to the work of the young poets of the time, among them Maurice Maeterlinck, Georges Rodenbach, and Émile Verhaeren, and was himself by no means "an emblematic figure of the décadence" of the era, as Christian Berg has put it:

He was rather emblematic of an entire generation, in particular that of La Jeune Belgique that wished to create a literature of trompe-l'œil or optical illusion in order to function, for several years, as an ironic simulacrum of the utilitarian and nationalistic passions that at the time still dominated Belgian literary and artistic circles. $^{37}$

His Pierrot lunaire brings together fifty rondels, a thirteenth-century poetic form that attained its apogee in the work of Charles d'Orléans, in the fifteenth century; a form that Théodore de Banville in particular returned to favor in the third book of his Cariatides of 1842 and his Rondels of 1875; a poetic form, in other words, that had now yet again come into fashion.

In the program note that accompanied the Parisian première of Zágon's Pierrot lunaire in December 1913 at the Société Musicale Indépendante (the note was published in Le Guide du concert), the composer explained the structure of the verses:

completed the printing of Pierrot lunaire by Albert Giraud. The work will be put on sale on 1 October." Some copies of Pierrot lunaire have the label of the Brussels publisher P. Lacomblez pasted over Lemerre's Paris address. This suggests that in fact the printing was carried out by both publishers.

35. Les Dernières Fêtes (9-72), Pierrot lunaire (73-176), Pierrot Narcisse (177-255).

36. In "Théâtre," the third line appears as follows in the 1884 edition: "Shakspear, les féeriques palais," (1); in the edition of 1898, it becomes: "Shakspeare, les pâles palais," (77). Likewise, in "L'Escalier," the third line appears as follows in the edition of 1884: "Turbule en bleuâtre poussière" (97); this, in the edition of 1898 , becomes: "S'irise en bleuâtre poussière" (173). In these two cases - the only variants we have discovered among the poems selected by the young Hungarian musician - Zágon follows the 1898 edition.

37. C. Berg, “» Prête-moi ta plume...«Pierrot, de Giraud à Schönberg,” 140. 


\begin{abstract}
All of the poems here assume the same form, one that is essentially musical: each poem comprises thirteen lines grouped into stanzas of four, four, and five lines. The seventh and eighth lines always correspond to the first and second lines; the thirteenth line always corresponds to the first. ${ }^{38}$
\end{abstract}

The refrain thus played a role that was at once rhythmic and musical. Another aspect of the formal structure of the rondel concerns the rhyme scheme of the two quatrains and the quintet: the first quatrain and the third (to which one added a line to form a quintet) bear closing rhymes (ABBA), while the second quatrain bears interlaced rhymes (ABAB). The structure thus turns upon two rhymes, one feminine, one masculine (Figure 2). It is therefore obvious that the poetry poses to the composer a particular kind of challenge. In fact, Albert Giraud, fiercely hostile to amorphous free verse poetry, chose furthermore to compose his entire collection in only octosyllabic lines, thereby following the most classical model possible.

Figure 2 Giraud, Héros et Pierrots (Paris: Fischbacher, 1898), pp. 105-106

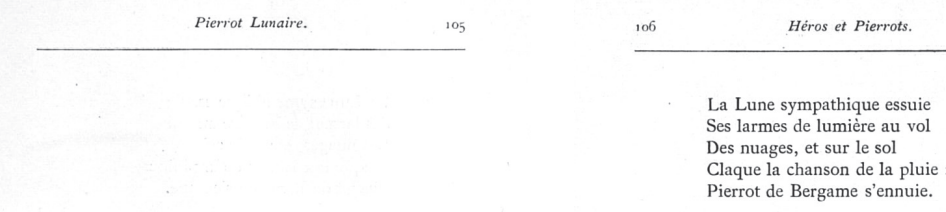

SPLEEN

Pierrot de Bergame s'ennuie

Il renonce aux charmes du vol

Son étrange gaîté de fol

Comme un oiseau blanc s'est enfuie.

Le spleen, à l'horizon de suie,

Fermente ainsi qu'un noir alcool.

Pierrot de Bergame s'ennuie :

Il renonce aux charmes du vol

38. Le Guide du concert 5/10 (13 December 1913), 154-155. This notice, we believe it logical to assume, is from the pen of Zágon. Indeed, in a letter of Émile Vuillermoz cited by Boglárka Illyés ("L’ambassadeur parisien," 284), Vuillermoz requests an article on his Sonata: "For the Guide du Concert (I've just arrived at home), please quickly write a notice and send it right away, with the enclosed card, so that it may be printed tomorrow." It is highly likely that for the December concert, Vuillermoz again asked that Zágon write an introductory essay. Indeed, the indication "nous dit l'auteur" ("the author tells us") would confirm that supposition. For a translation of the text about Zágon's Pierrot lunaire that appeared in the Guide du concert, see Appendix 2. 
From Giraud's fifty rondels bergamasques, Zágon selected six, while Arnold Schoenberg would select twenty-one (which he would group into three equal sets of seven). The only poems that both composers set are "Messe rouge" ("Rote Messe") and "Départ de Pierrot" ("Heimfahrt"). ${ }^{39}$ Zágon chose the first poem of the collection ("Thêatre"), the fifteenth ("Spleen"), the twenty-ninth ("Messe rouge"), the forty-first ("Poussière rose"), the forty-ninth ("L'Escalier"), and, to close the cycle, the thirty-sixth ("Départ de Pierrot"). With the exception of the final song, then, he followed Giraud's ordering, which Schoenberg most certainly did not. In Le Guide du concert of December 1913, Zágon described the atmosphere created by Giraud's poems:

The poems resemble those of Verlaine's Fêtes galantes in terms of the ideas and emotions that motivate their personages, impassioned "masks" upon whom are reflected tender souls like that of Schumann. At the same time, however, as the author tells us, these are just so many sumptuously painted images that evaporate in the pale blue of one's dreams. The piano is not constrained to a simple accompaniment; it plays a role that is both important and independent. ${ }^{40}$

As Paolo Budini notes, in his study of "Le Rondel d'Albert Giraud," "the rondels of Pierrot lunaire, while evoking Parnassian rigor by means of the perfection of their forms, overlook neither the melancholic atmosphere of Les Fleurs du mal nor the morbid elegance of Les Fêtes galantes." "Il "It is nonetheless the case," he adds, "that these rondels, these miniature tableaux, these bejeweled enamels, maintain today all of the fragrance and freshness of their era." ${ }^{.42}$

The autograph manuscript of Pierrot lunaire, with Debussy's revisions, was never brought to publication during Géza Vilmos Zágon's lifetime, despite the interest in it that was expressed in June 1914 by the Parisian publisher Albert Zunz Mathot. ${ }^{43}$ It has come down to us thanks to the purchase by the Széchényi National Library, in 1942, of the papers and manuscripts of Zágon's brother, the composer Sándor Zerkovitz. ${ }^{44}$ The manuscript (Ms. Mus. 2.022) is encased in an orange paper cover on which Zágon set down the title of the work as well as the

39. Respectively, the eleventh ( $2^{\text {nd }}$ Part) and nineteenth ( $3^{\text {rd }}$ Part $)$ of Schoenberg's Pierrot lunaire, op. 21.

40. Le Guide du concert 5/10 (13 December 1913), 155. See Appendix 2.

41. Paolo Budini, "Le rondel d'Albert Giraud," Francofonia 16 (Spring 1989), 62.

42. Paolo Budini, "Le rondel d'Albert Giraud," 63.

43. We know of Mathot's interest from a letter transcribed by Boglárka Illyés in "L'ambassadeur parisien," 276, dated 15 June 1914: "If you like, I will be delighted to give hospitality to your Pierrot lunaire of which, as you know, I have a very good impression. Should you be in agreement, it will be necessary for you to send me the autograph manuscript accompanied by a letter similar to the one you provided to me for your Jeux de vagues. I enclose here the text of the letter such that, again assuming your agreement, you need only sign. I will of course be able to fix the price of the collection only after having examined the manuscript." Despite my research in the archives of Salabert, the firm that took over the Mathot publishing company in May 1930, I have been unable to find Zágon's manuscripts.

44. See Boglárka Illyés, "L’ambassadeur parisien," 257. 
titles of the rondels he had set to music. It encompasses twelve folios of music of which the versos of five remain blank. Each song is preceded by an autonomous title page on which appears the name of the poem and, at the bottom, in blue pencil, the date of the composition. This leads to the following chronology:
I. "Théâtre." "Le 15 Octobre 1908"
II. "Spleen." "Le 29 Janvier 1909"
III. "Messe rouge." "Le 26 Février 1909"
IV. "Poussière rose." "Le 4 Mars 1909"
V. "L'escalier." "Le 1er Avril 1909"
VI. "Départ de Pierrot." "Le 10 Septembre 1909"

The music paper used by Zágon for the first five songs is of a format measuring $26.5 \mathrm{~cm}$ wide by $34.5 \mathrm{~cm}$ high, with twelve staves per page (printed in a voiceand-piano format). It was produced by the Viennese firm of J. Eberle ("J.E \& $\mathrm{C}^{\circ}$. I Protokoll Schutzmarke / $\mathrm{N}^{\circ}$. 12"). The paper used for the "Départ de Pierrot" is of the same format, and comes from the same Viennese firm ("J.E \& C $\mathrm{C}^{\circ}$. / Protokoll Schutzmarke / №. 6"), but it is printed with twenty equal staves (without piano format). The music, notated in black ink, fills thirteen pages. On eleven of these, we find corrections in the hand of Claude Debussy (Figure 3).

Attached to this manuscript is another autograph, this one composed of four folios likewise wrapped in an orange paper cover marked in Zágon's hand with the title of the cycle and including the vocal parts for four of the six songs: "Théâtre," "Spleen," "Messe rouge," and "Départ de Pierrot." The format measures $20.5 \mathrm{~cm} \times 26.5 \mathrm{~cm}$; the paper is from the same Viennese firm (now "J.E \& $\mathrm{C}^{\circ}$. / Protokoll Schutzmarke / No. 63") with twelve printed staves per page. Following this second gathering, we find a typescript with the texts of the six poems and the program of the first performance in France, at the Société Musical Indépendante, on 17 December $1913 .{ }^{45}$

A comparison of the separate vocal parts and the voice-and-piano manuscript shows that the former do not include the corrections made by Debussy, and that, except for "Départ de Pierrot," they are notably different from the original. For example, at the beginning of "Théâtre," at measure 7, Zágon notated an eighthnote $G$ under the last syllable of the word "Shakespeare" (Example la). This was changed, in the voice-and-piano score, to an eighth-note $C$, below (Example $1 b$ ). Furthermore, in measure 12 (Example 2a), the prosody at the beginning of the line ("Par les frileux soirs de décembre") is modified by starting one eighth-note soon-

45. After the program we find a page from the journal Pesti Hirlap (25 December 1937) with an article by Viktor Lányi ("Debussy és a magyar népzene. A nagy francia zeneköltő ismeretlen magyar vonatkozású levele") in which there is a facsimile reproduction of Debussy’s letter to Gusztáv Bárczy of 19 December 1910, cited at the beginning of this article. 
Figure 3 Zágon, Pierrot lunaire, "Messe rouge," fol. 7r, mm. 17-33, with corrections by Debussy at mm. 22-23, 26, and 28 (H-Bn, Ms. Mus. 2.022)

(With kind permission of the National Széchényi Library, Budapest)

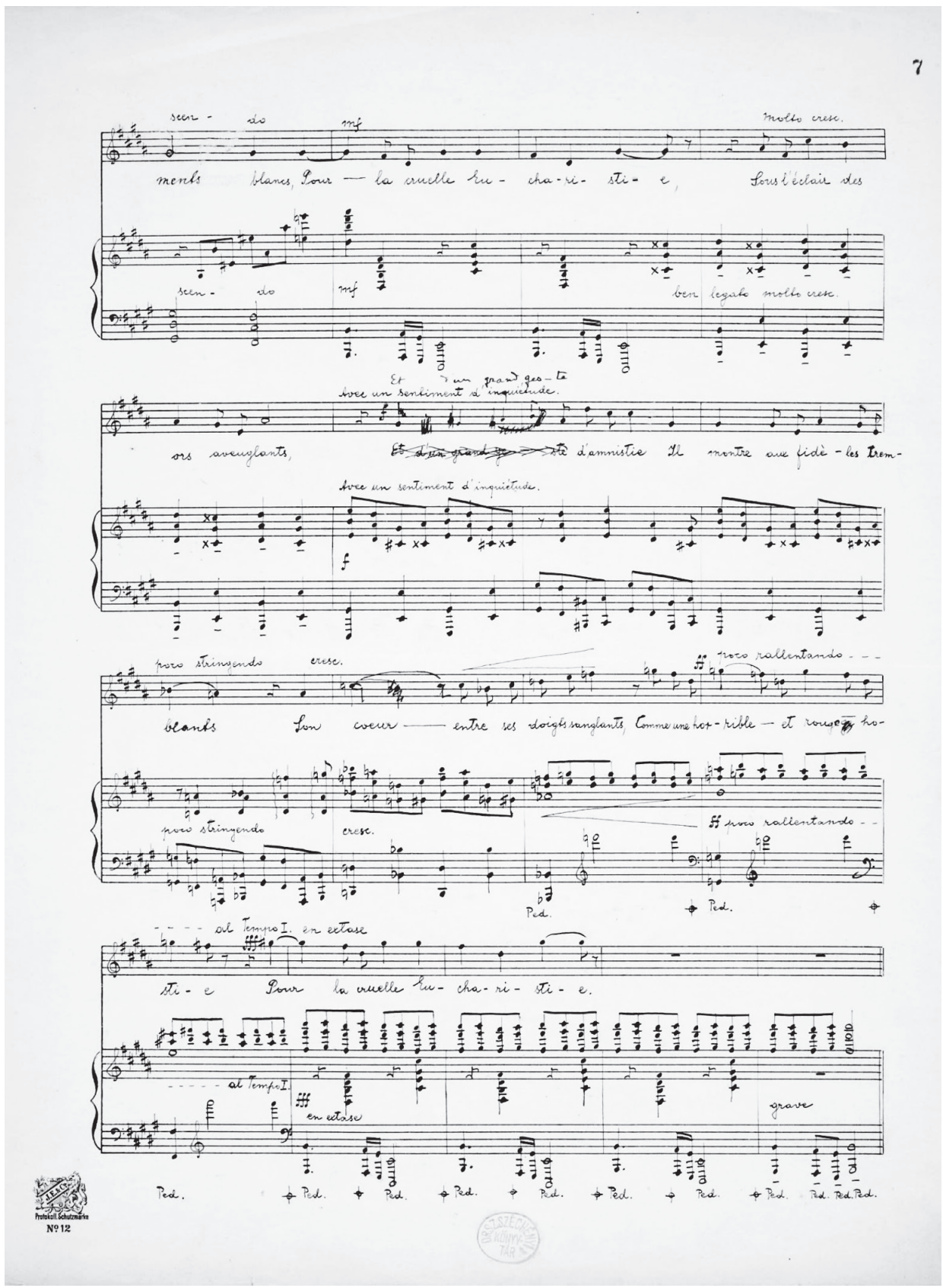


er, on a $D$, and by elongating by an eighth-note the syllable "-leux" of "frileux" (Example 2b). The vocal parts would thus seem to have been set down prior to the time at which the voice-and-piano autograph was corrected and cleaned up. They demonstrate that the question of prosody was of constant concern to Zágon throughout his work; they explain what motivated him to submit his Pierrot lunaire to the distinguished French composer.

Example 1a-b Zágon, Pierrot lunaire, "Théâtre," mm. 6-7

a)

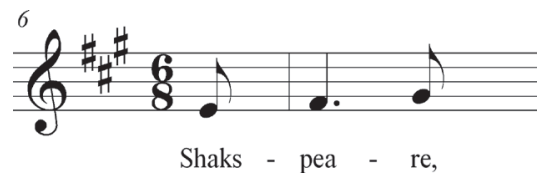

b)

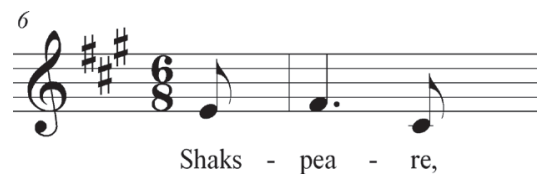

Example 2a-b Zágon, Pierrot lunaire, “Théâtre,” mm. 12-13

a)

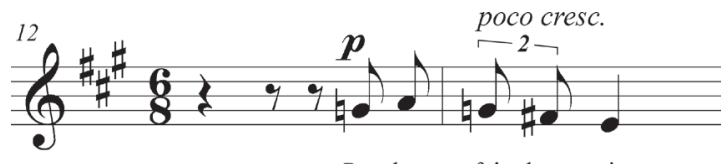

Par les fri - leux soirs

b)

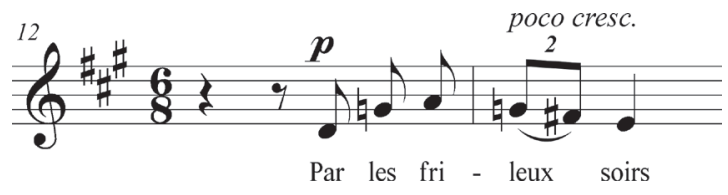

On 22 January 1911, Debussy returned to Zágon the voice-and-piano manuscript that he had received at some point between 7 and 19 December 1910. He accompanied it with a letter explaining the nature of the corrections that he had made. ${ }^{46}$ The letter opens as follows: "Cher Monsieur, along with this letter you will receive the score of your Pierrot lunaire with the corrections I felt it neces- 
sary to make, almost all of which, in fact, concern the prosodic accents." Now, it happens that the question of "prosodic accents" has been an object of study since the eighteenth century, and has resulted in a variety of definitions, some simple, some complex. Briefly, "prosodic accent" refers to the highlighting or bringing to the fore of a few syllables that lie at the heart of a poetic line. As Paolo Budini points out: "The octosyllabic lines of Pierrot lunaire, although quite varied in their rhythmic schemes, very often emphasize two tonic syllables, the second and the fifth, which are added [to the emphasis upon] the eighth and final syllable."${ }^{, 47}$ It is not difficult to understand why Zágon was befuddled by the problem of prosodic accents. Debussy's corrections in this regard are extremely precise. Let us examine each of them, song by song.

We begin with the first, "Théâtre," which Zágon described in Le Guide du concert of December 1913 as "a kind of prologue that sets out the location of the events to take place and presents some of the personages of the »mimodrame «."48 Debussy's corrections occur at the end of the piece, in measures 23 and 24, then in measure 26 (Example 3). In measure 24, Zágon had placed the word "laids" on a strong beat, something which - considering the accents of the line ("On y verrait les Crispins laids"), which fall on the fourth and eighth syllables ("-rait" and "laids") - was in fact not wrong, although this rhythm, as we have just seen, was not the most common one for the octosyllabic line. The change proposed by Debussy has the advantage of avoiding too much weight on the syllable "-pins" of "Crispins" with a quarter-note $E$-flat and an eighth-note $D$, of lightening the first beat of measure 24 by means of an eighth-note rest, and of highlighting the opening of the following line by elongating the syllable "Oua-" of "Ouater." $\mathrm{He}$ furthermore facilitates the comprehension of the end of the first line ("Crispins laids"), which is rather complicated when one does not have the text before one's eyes. As for measure 26 (Example 3), where the rhythm of the line ("Pour Colombine qui se cambre") is identical to the preceding line, Zágon had perfectly placed the prosodic accents on the "-bi" of "Colombine" and on the "cam-" of "cambre." Debussy thus had no need to modify the rhythms, but he did change the pitches in order to underline the importance of these syllables: a dotted-eighth $A$ rather than a dotted-eighth $G$-natural, in the first case, and an $F$-natural rather than a $C$-naturel in the second, something that breaks the conjunct and gently chromatic motion set out by Zágon and replaces it with the more expressive interval of the fifth.

47. Paolo Budini, "Le rondel d'Albert Giraud," 67.

48. Le Guide du concert, 155 (see Appendix 2). Zágon's analysis converges with that of Paulo Budini ("Le rondel d'Albert Giraud," 78), which sees in this opening rondel "a kind of dramatic prologue," with evocations of Breughel (a painter whose work Giraud was particularly fond of), of Shakespeare ("the site of somber tragedies"), and of Watteau (“the painter of masks [masques]"). 
Example 3 Zágon, Pierrot lunaire, “Théâtre,” mm. 22-26

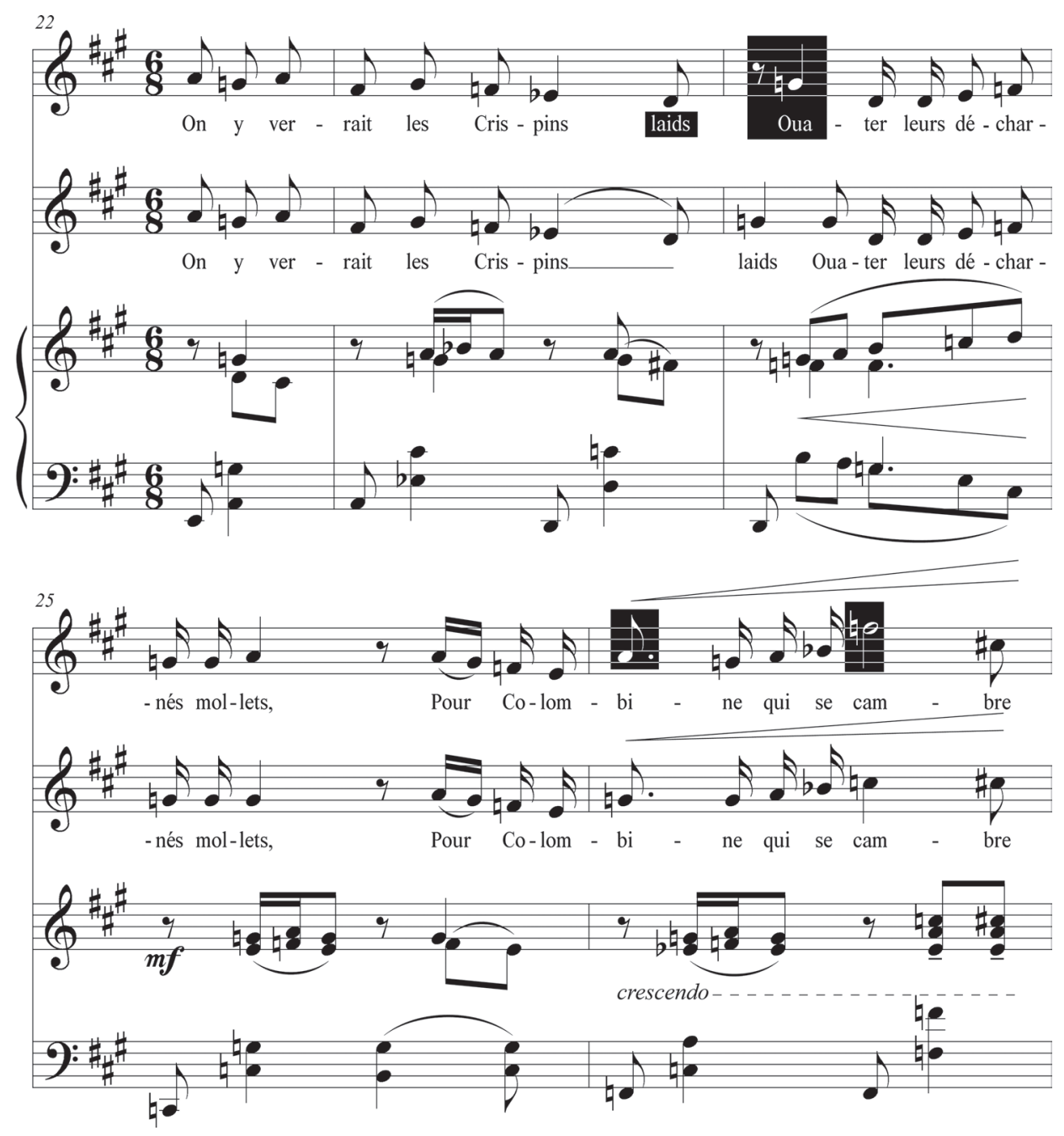

"Pierrot from Bergamo" is bored, while the "Song of the rain" batters the windows, such is the commentary of the young Hungarian musician in Le Guide $d u$ concert on the second song of the cycle, "Spleen." Debussy's corrections here concern the refrain of this rondel, "Pierrot de Bergame s'ennuie," which appears, as is traditional, at the first, seventh, and thirteenth lines (Example $4 a-c$ ). Musically, the vocal part is structured on the same notes, with the rhythmic variants, while the piano part is alike upon the first two appearances of the refrain, but different upon the third. In this particular case, Debussy does not modify the pitches ( $B$ and $E$ ), but each time he removes the note $A$ for the syllable "s'en-" 
of "s'ennuie," which, along with the interval of the major third, sets in relief the end of the line. By contrast, he modifies the rhythms of the line of "Spleen" that reproduces the most frequent rhythm of the octosyllabic verse, with accents upon the second, fifth, and eighth syllables, in this case, upon the "-rot" of "Pierrot," the "-ga-" of "Bergame," and the "-nuie" of "s'ennuie." Zágon had emphasized these syllables with a dotted quarter note for the "-rot" of "Pierrot" and a half-note and dotted quarter-note" for the "-ga" of "Bergame." Debussy will avoid an overly long extension of the line, in the opening measures, by having the voice begin in the middle of measure 2 instead of on the upbeat to measure 1 , something that avoids placing the syllable "-rot" on the first beat of measure 2 (Example $4 a$ ). $\mathrm{He}$ will also modify the pitches for "Bergame," a particularly evocative name in his imagination, as we shall see below. Zágon had systematically set the two syllables "de Ber-[game]" to a descending fifth, $B$ to $E$, which had the disadvantage of accentuating the first syllable, "Ber-," rather than the second, "-ga-." The same changes were made in measures 13-15 (Example 4b), and in measures 25-26 (Example 4c). Finally, Debussy indicated to Zágon in measure 26 that the final "e" of "s'ennuie" must remain mute, as the Hungarian composer had notated the word on its first two appearances.

In the third song of the cycle, "Messe rouge," we attend "Pierrot's gruesome ceremony in which he holds "up his heart, to the terrified faithful, in his bloody fingers,' with the piano concluding in a violent sounding of church bells," as Zágon writes in his note for Le Guide du concert ${ }^{49}$ The melancholic Pierrot of "Spleen" thus gives way to the highly macabre Pierrot of this song. Here Debussy made only a few changes, in measures 22-23, 26, and 28 (Figure 3).

In the first instance (Example $5 a$ ), he corrected a gesture in order to avoid the note $E$ for the word "d'un" and changed the rhythm to three quarter-notes, which

Example 4A Zágon, Pierrot lunaire, "Spleen,” mm. 1-3

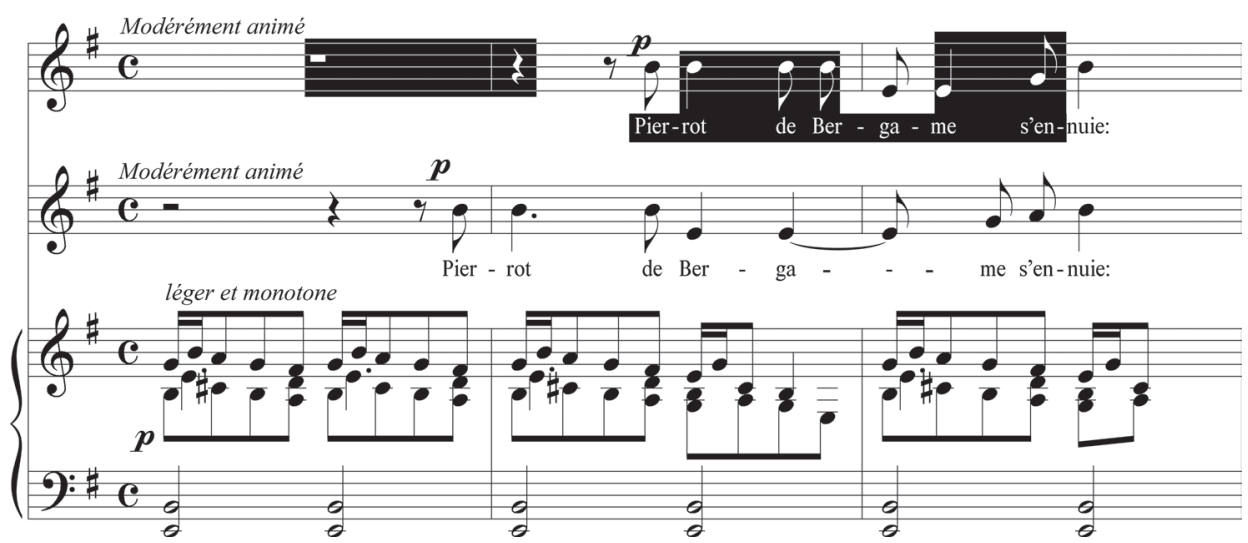

49. Le Guide du concert, 155 (see Appendix 2). 
Example 4в Zágon, Pierrot lunaire, "Spleen," mm. 13-15

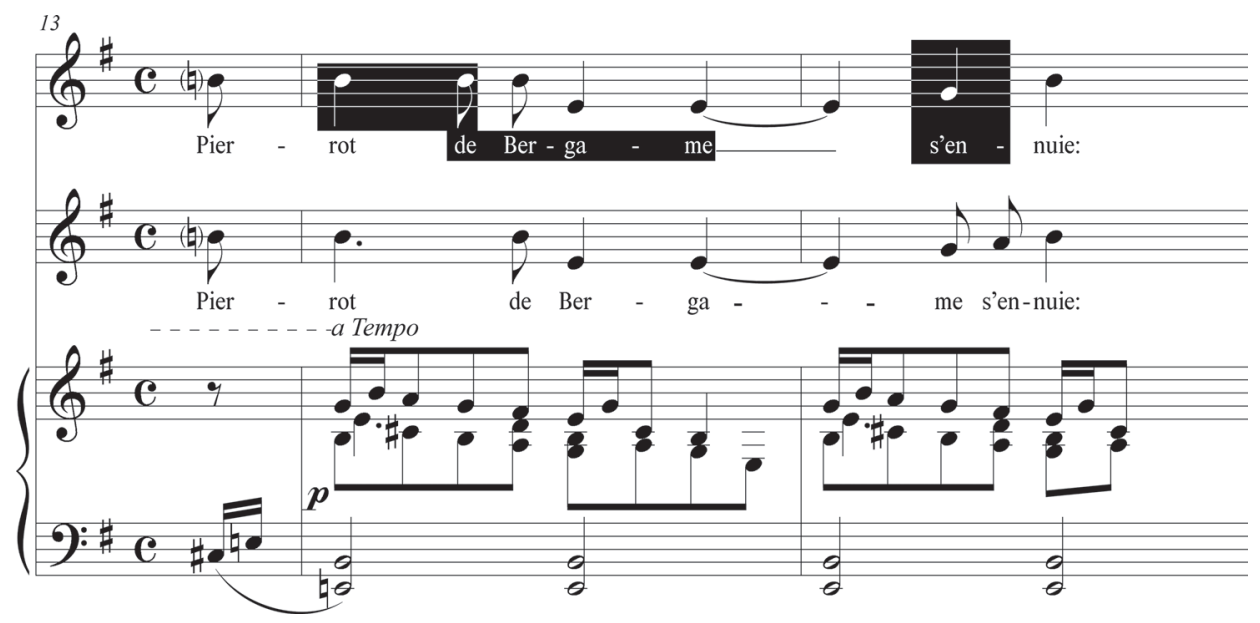

EXAMPLE 4c Zágon, Pierrot lunaire, "Spleen,” mm. 24-26

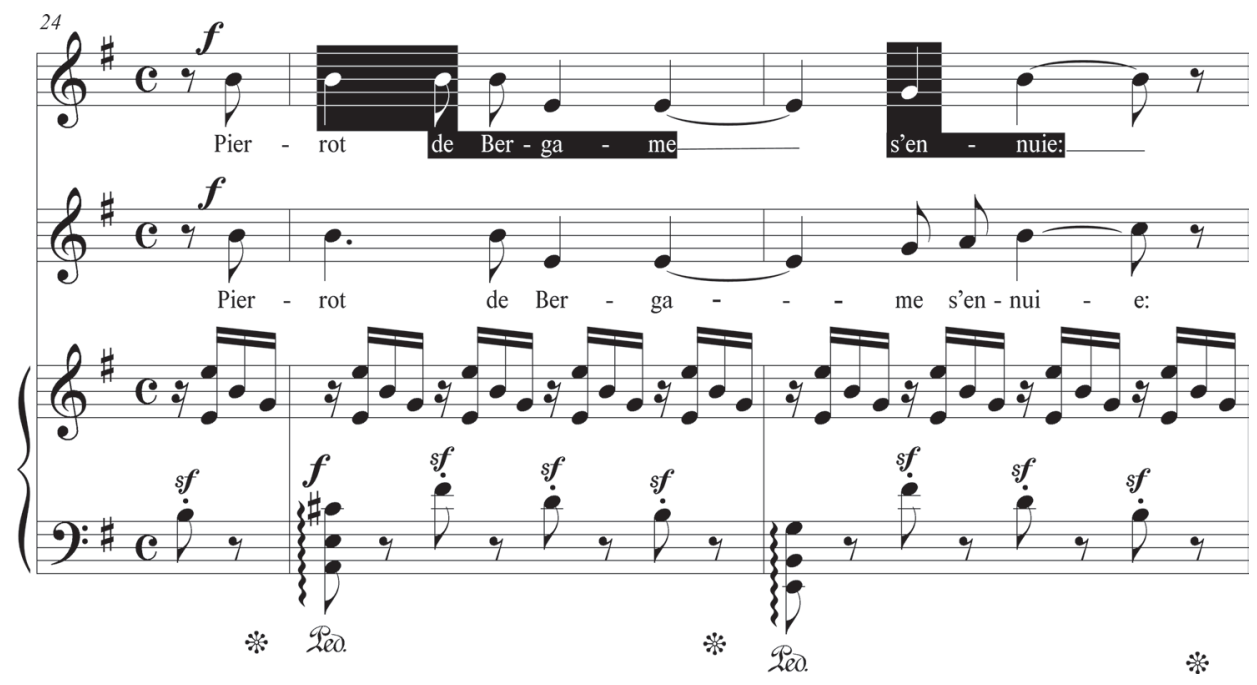

renders more comprehensible the beginning of the line ("Et d'un grand geste") and removes the uselessly strong accent on the syllable "ges-" of "geste." In measure 26 (Example 5b), Debussy avoided the falling major second for "cour" and eliminated the eighth rest in order to preserve the verve of this line, which represents the culmination of this most chilling rondel. At measure 28 (Example 5c), Zágon had set the two separate syllables of "rou-ge" to a quarter-note and eighthnote. Debussy places the word "rouge" beneath the quarter-note and adds a slur to the eighth-note in order to avoid emphasis on the final, mute e of the word. The limited number of changes here no doubt reflect Debussy's lack of enthusiasm 
for this third song, something he will mention in his letter to the composer of 22 January 1911: "In particular, I should like to call to your attention the somewhat forced tessitura of »Messe rouge «. Do you not think that a voice that would sound well at both the beginning and the ending will be difficult to find? Perhaps it might be wise for you to modify the ending." Debussy criticizes the composer for concluding the repetition of the initial line of the rondel one octave higher than at the

Example 5A Zágon, Pierrot lunaire, “Messe rouge,” mm. 22-23

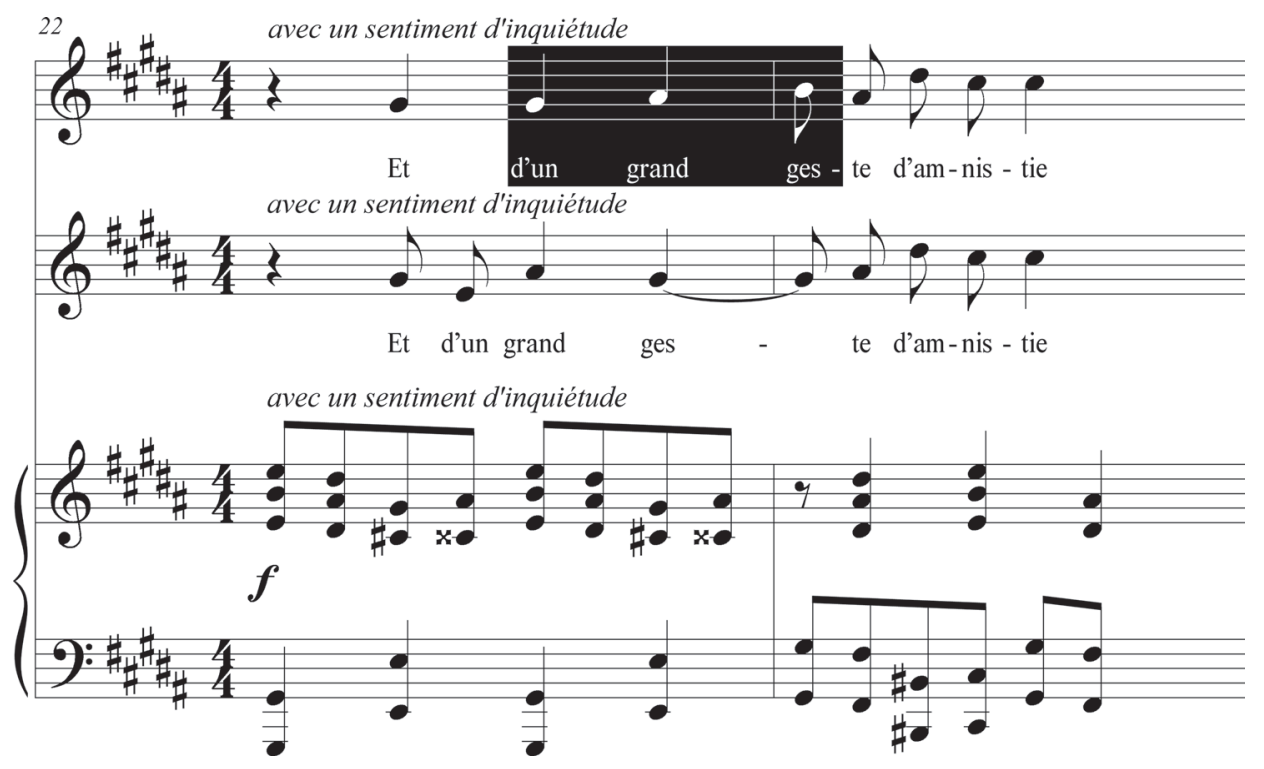

Example 5в Zágon, Pierrot lunaire, “Messe rouge,” mm. 25-27

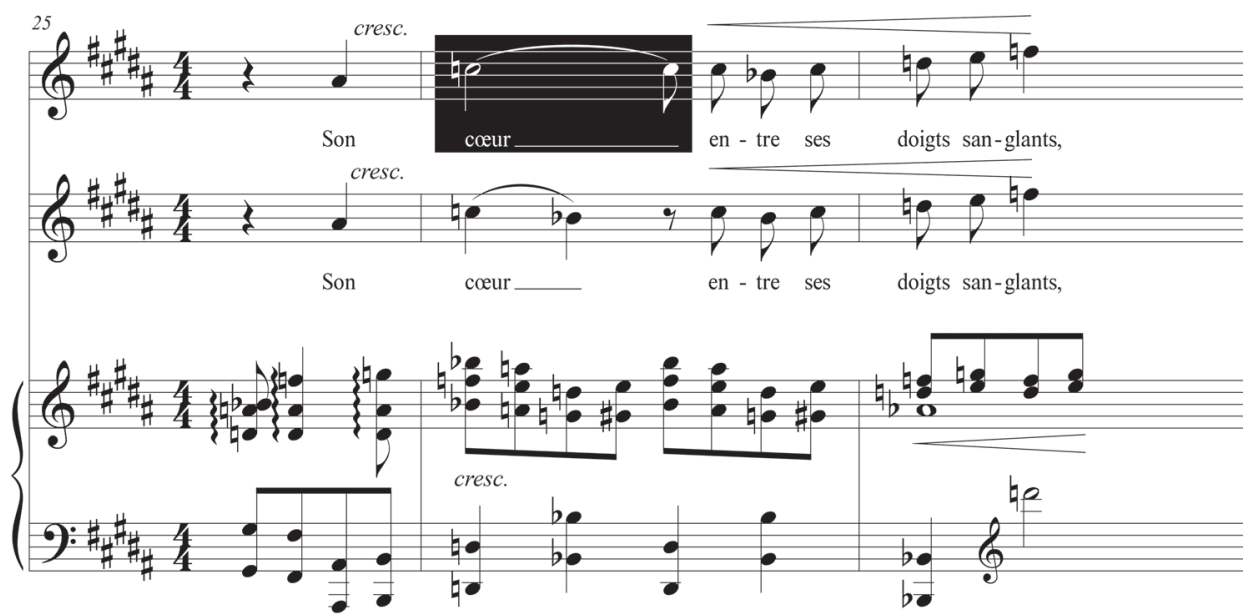

Ter. 
ExAMPLE 5c Zágon, Pierrot lunaire, "Messe rouge," m. 28

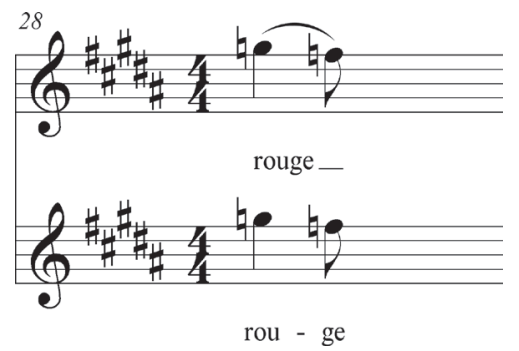

outset, with quadruple fortissimo on a high $G$-sharp, the effect of which would in all likelihood be shrill.

In the fourth song of the cycle, "Poussière rose," whose character Zágon describes as "imprinted with the civility and the freshness of the morning," Debussy slightly modifies measures 5 and 20, which correspond to the octosyllabic line "Danse à l'horizon du matin." This appears in the rondel as the second and eighth line, as one would expect, and with the expected accentuation. Debussy thus adds an eighth rest at measure 5 (Example 6a), providing a welcome breath between two lines and avoiding stress on the already stressed first beat of the measure. Furthermore, by removing the melisma on the "Dan-" of "Danse," which was already awkward by dint of its elision to the following syllable, Debussy avoids a prosodic accent on that same first syllable. This small change enhances the airiness of expression that Zágon seems to have wished to achieve. Debussy's second correction in "Poussière rose" occurs in measures 23-24 (Example 6b). Zágon, apparently attempting to evoke the atmosphere of dancing, set the "-dre" of "Cassandre" and the "mo-" of "morose" to two sixteenth-notes, as he did the "-se" of "morose." Debussy modified that rhythm, removed the pattern of eighth followed by two sixteenths, added an eighth-note F-natural to the "-dre" of "Cassandre," and emphasized the final syllable, "-rose," of "morose," with an eighth-note replacing the two sixteenths. In the following line, Zágon had placed the prosodic accent on the "fal-" of "falbala" (by means of an eighth-note) rather than on the "-la," that is, on the fifth syllable of the line. Debussy corrected the passage by reversing the rhythm from eighth followed by two sixteenths to two sixteenths followed by an eighth.

The fifth song of the collection, "L'Escalier, despite a title that is hardly poetic, is an evocation of Pierrot's devotion to Colombine," ${ }^{50}$ as Zágon puts it in Le Guide 
252

Denis Herlin

Example 6a Zágon, Pierrot lunaire, "Poussière rose,” mm. 1-6
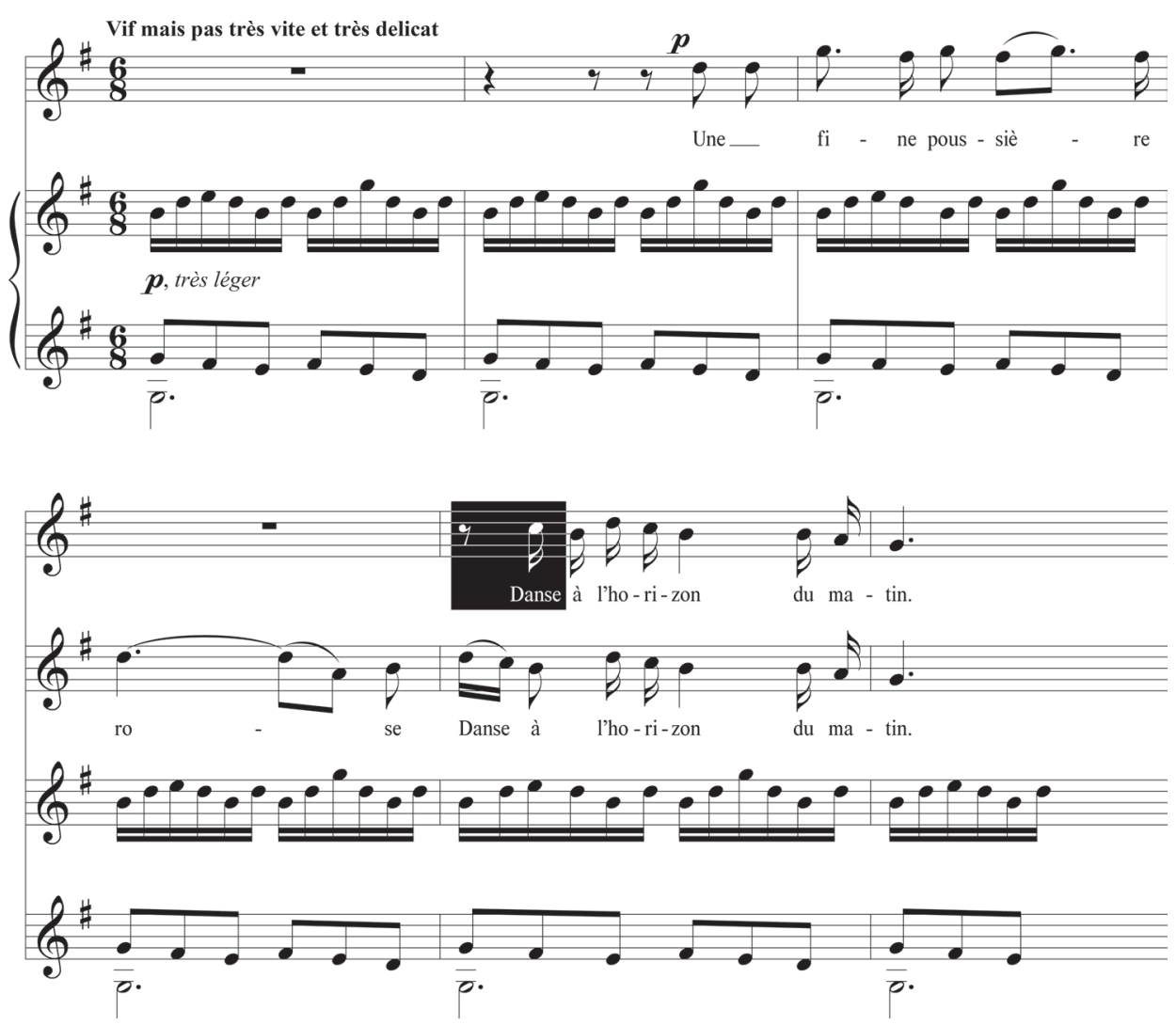

EXAmple 6в Zágon, Pierrot lunaire, “Poussière rose,” mm. 22-25

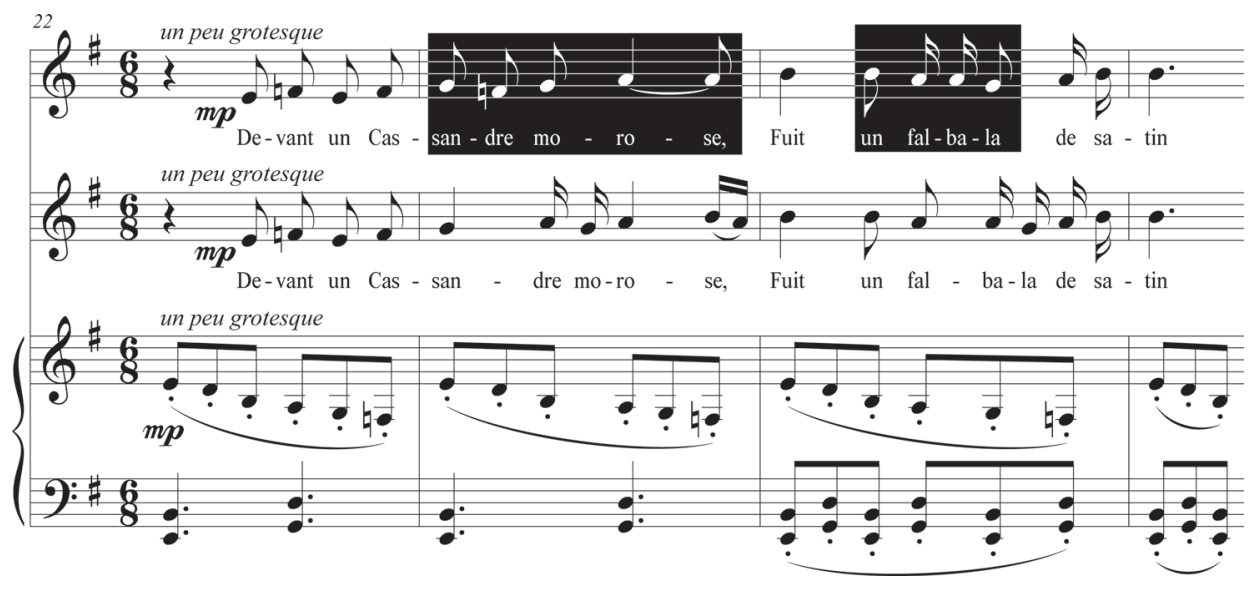

Studia Musicologica 59, 2018 
$d u$ concert. Debussy corrected measures $12-13,16$, and $22-23 .{ }^{51}$ As in the previous songs, here, too, he modified the prosodic accent in order to make it conform to the rhythm of the poetic line. Thus, after adding a natural-sign in pencil before the $B$ (in the vocal part) of measure 11 (Example 7a), he corrected the rhythm of the octosyllabic phrase "Fait, dans sa ronde coutumière," whose accents fall on the fourth and eighth syllables. The "-de" of "ronde," too heavily inflected with an eighth-note $F$ on the second beat, was changed to a sixteenth-note $F$ that is no longer on the beat, something that allows for a smoother connection to the following words of the line. Further smoothness is achieved by changing to a $G$ Zágon's A-flat for the "-re" of "coutumière," something that would create an inappropriate inflection. In measures 16-17 (Example 7b), Zágon had conceived a melisma on the "-ger" of "léger," and another on the "lu-" of "lumière." Debussy maintained the latter, but removed the former and rather placed it on the "de" of measure 16, which allowed him to lighten the accent on the "-ger" of "léger" and to bring to the fore the emphasis on the second syllable of "froufrou." (Curiously enough, Debussy did not make these changes in measures 3-5, in the octosyllabic line that belongs to the refrain and thus to the second and eighth lines of the rondel.) Finally, measures 21-22 were likewise transformed (Example 7c). Debussy's changes were necessitated by the positioning of the syllable "-rière" of "prière": Zágon had placed it on the first beat of measure 22, failing to take account of the diaeresis and thus of the necessity of breaking the syllable into two parts. In order to fit the "pri-" of "prière" into the end of the measure, Debussy shortened to an eighth-note the dotted eighth-note Zágon had written for the "blan-" of "blanche." Furthermore, in the following measure, Zágon's quarter-note on the word "grand" gave that word too much weight. Debussy fixed matters by adding a melisma on "De," which allowed him to displace the syllables and to set the word "grand" to only an eighth-note $D$-flat.

Like "Messe rouge," the final song of Zágon's Pierrot lunaire, entitled "Départ de Pierrot," also led Debussy to make an extended commentary in his letter to the composer of 22 January 1911:

The music that describes Pierrot's departure seems to me to be less felicitous than that of the other pieces... To be perfectly honest, it is more lunaire [that is, more wacky] than Pierrot. In the poem, there is a kind of animation, a kind of fantasy, that is simply not found in your music. It seems to me that you ought to attempt to try to find something better, namely, something that would preserve all of Pierrot's moonstruck melancholy while at the same time surrounding it with lighter, more evanescent rhythms. ${ }^{52}$

51. At the beginning of measure 15, Zágon had incorrectly separated the syllables of the word "l'escalier" ("e-sca-lier"); Debussy corrected the divisions ("es-ca-lier").

52. The letter appears in Appendix 3. 
Example 7A Zágon, Pierrot lunaire, “L'Escalier," mm. 9-13
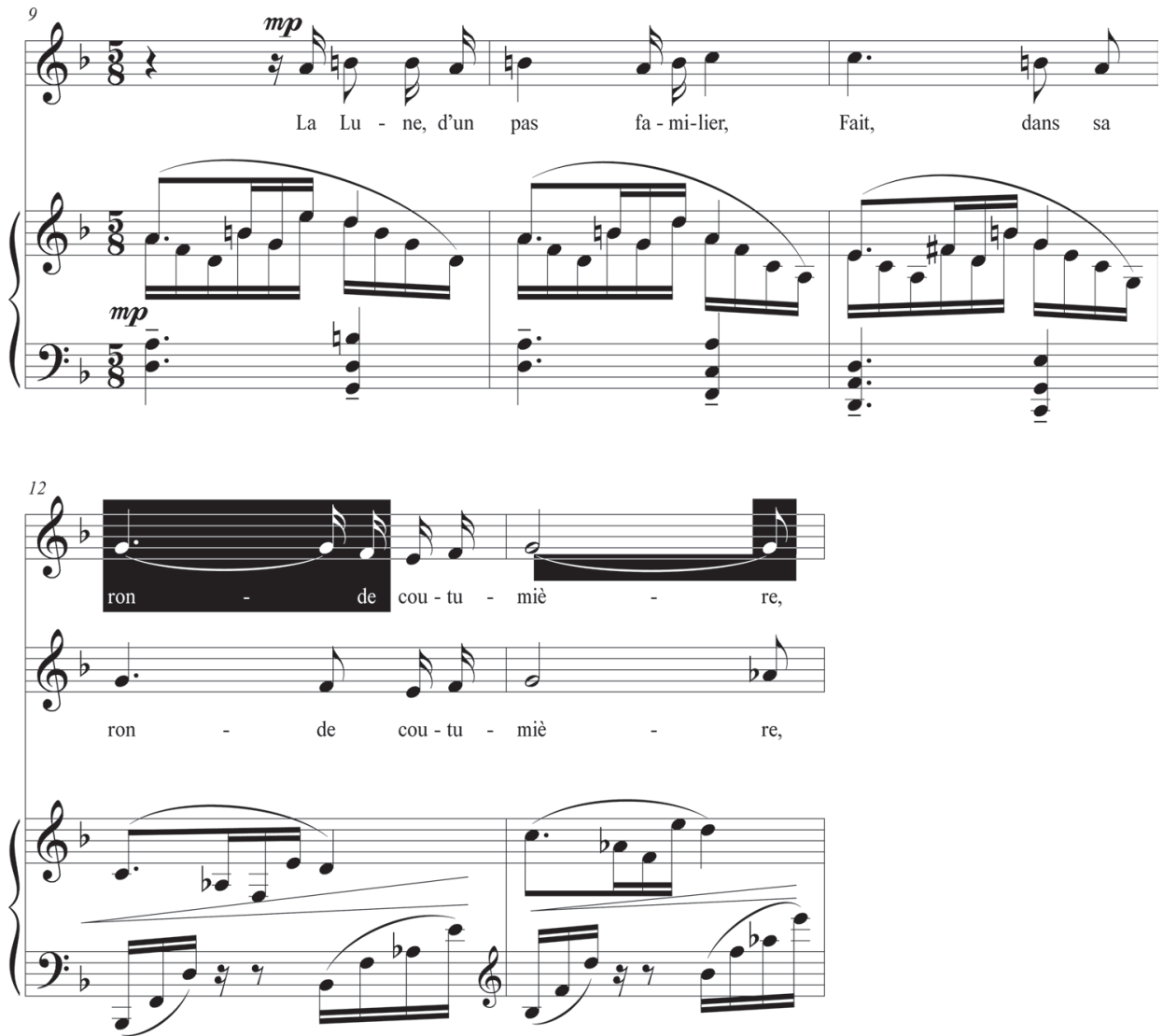

EXAmple 7в Zágon, Pierrot lunaire, “L'Escalier,” mm. 15-17

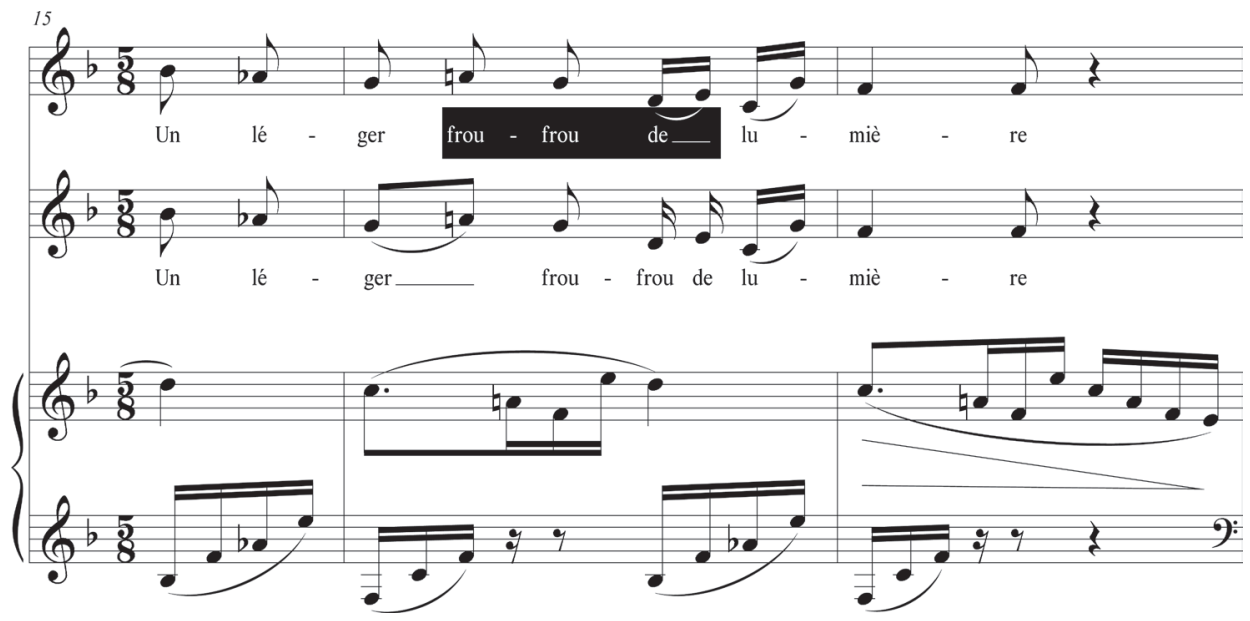


Example 7c Zágon, Pierrot lunaire, “L'Escalier,” mm. 20-24

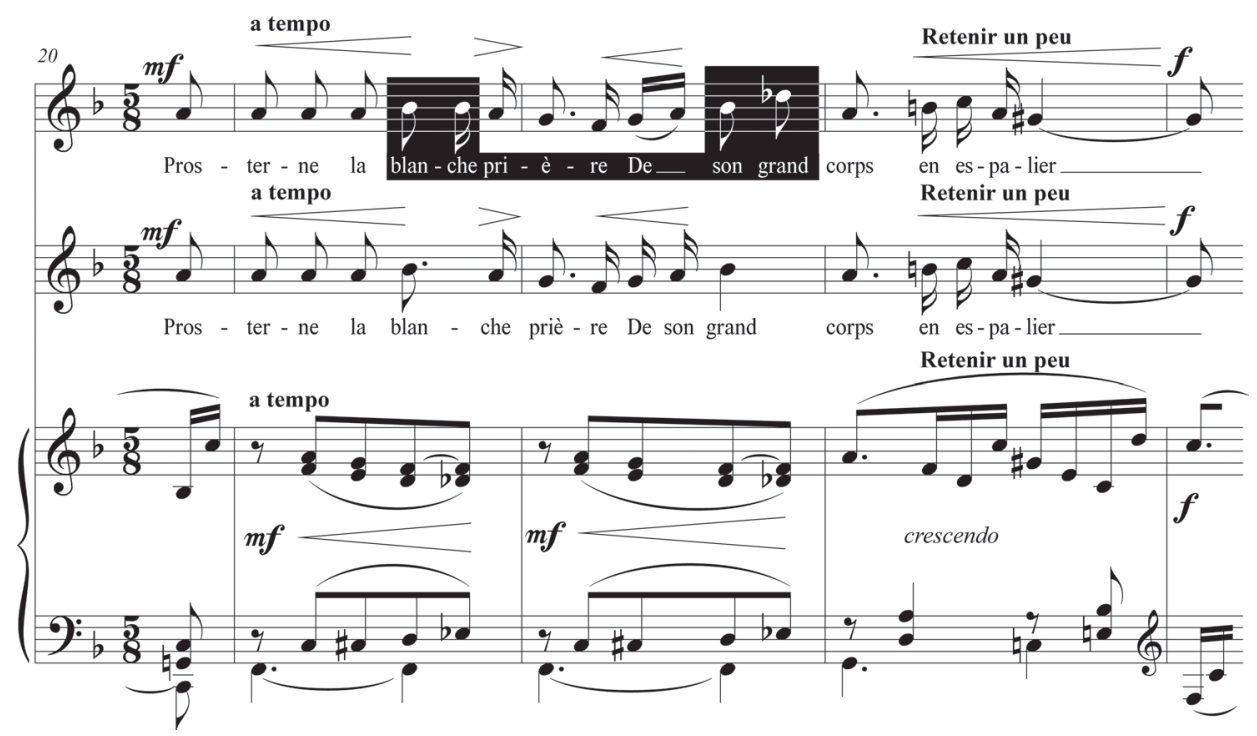

The corrections that Debussy did make here are rather difficult to read, and, for the first time, they concern not only the vocal line but also the piano accompaniment. They involve almost uniquely the first two lines of "Départ de Pierrot": "Un rayon de lune est la rame, / Un blanc nénuphar, la chaloupe," which, following the conventions of the rondel, reappear in the seventh and eighth lines, and then in the thirteenth. Debussy modified the piano and voice parts in measure 1 as well as in measure 4 (Example 8a). Zágon had placed the prosodic accent on the first syllable of the word "rayon" rather than on the second, where it belonged, even though the syllable "-yon" was the third of the line. As Paolo Budini has pointed out regarding the octosyllabic lines in Giraud's poetry, "the tonic accent is sometimes prepared for the third syllable by being preceded by a weak accent on the first." 53 Because the vocal line was originally doubled by the piano, Debussy invented a short piano introduction, in order to present the first two syllables of the line on the last beat of the measure. Furthermore, he placed the fifth syllable (the "lu-" of "lune") on the third beat of the measure rather than on the fourth, where Zágon had placed it. Finally, in the second line, he shortened to a dotted quarter-note the setting of "blanc" and prolonged to a dotted quarter-note the setting of the last syllable of "nenuphar," thus following the classic rhythm of octosyllabic verse. Having revised measures 1-4, Debussy then carried his revisions over to measures 15-17 (Example 8b), and to measures 27-28 (Example 8c), that is, to the measures 
that set the repetitions of the poetry. At the end of the song, Debussy changed the setting of the preceding line in order make room for the first two syllables of "Un rayon." Finally, he altered the rhythm to allow for greater weight upon the final syllable of the word "horizon."

In the end, even after examining all the changes that Debussy made to the score, it is not possible for us to know with certainty that Zágon actually followed the French composer's advice. However, we do possess a second autograph manuscript of the song "Messe rouge," which is preserved with the papers of Pongrác Kacsóh (1873-1923), in the Széchényi National Library, under the shelf-mark Ms. Mus. 938, and whose format, number of staves, and watermark are identical to those of the manuscript Ms. 2.022. ${ }^{44}$ Here we see that Zágon did not modify the ending of the song as Debussy had suggested, but that he did otherwise accept all

Example 8A Zágon, Pierrot lunaire, “Départ de Pierrot,” mm. 1-4

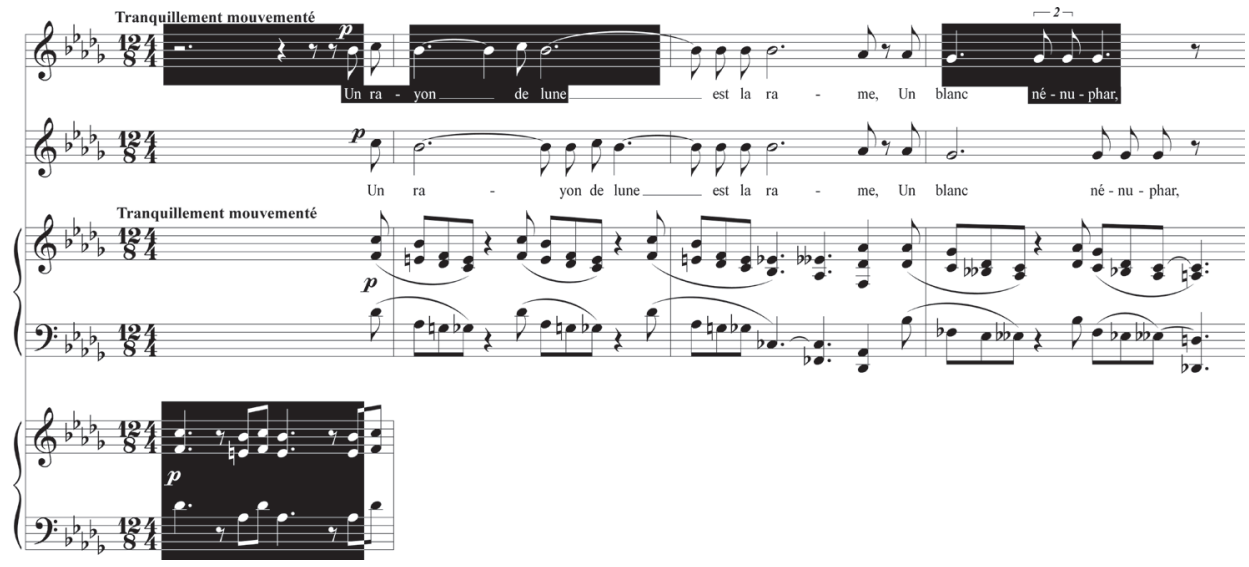

Example 8в Zágon, Pierrot lunaire, “Départ de Pierrot,” mm. 15-18

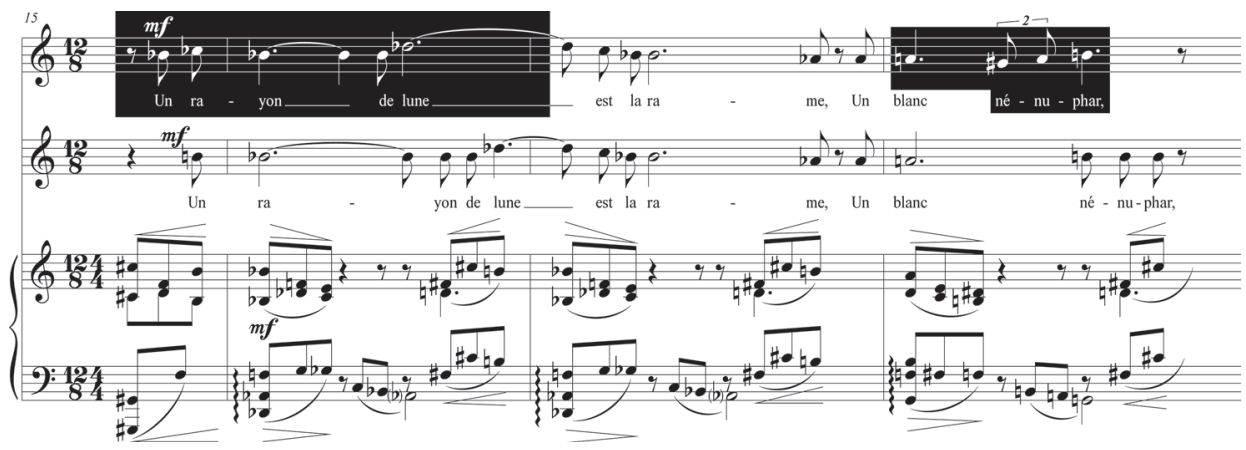

54. The format is $26.5 \mathrm{~cm} . \times 34.5 \mathrm{~cm}$., with twelve staves (the piano part, with one supplementary staff); the paper is that of the Viennese firm J. Eberle: "J.E \& C $C^{\circ}$ / Protokoll Schutzmarke / No. 12." 
Example 8c Zágon, Pierrot lunaire, "Départ de Pierrot," mm. 26-28

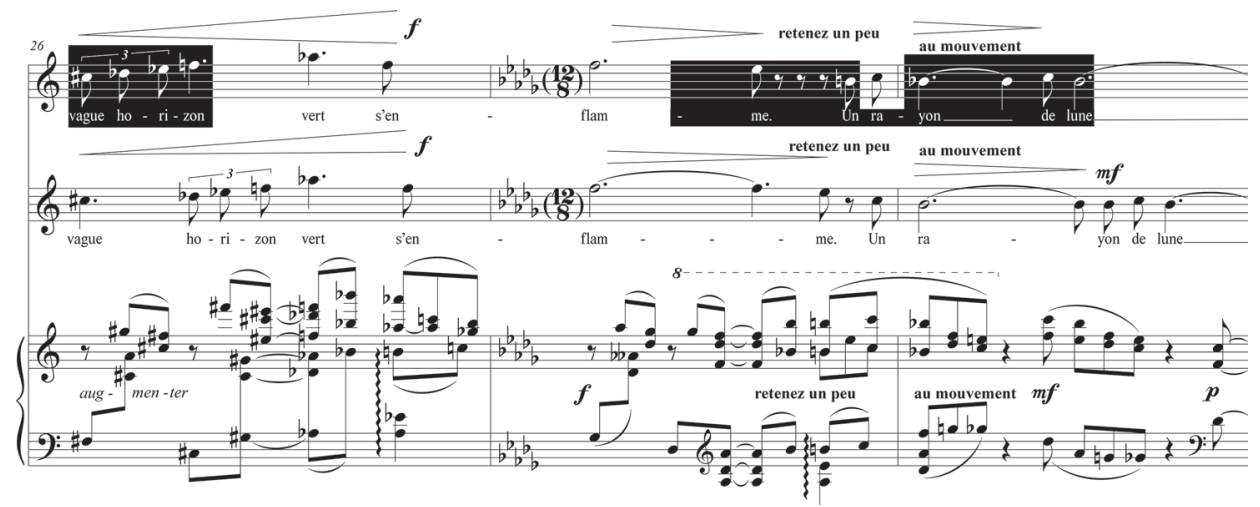

the corrections that we have described and that are indicated in Examples $5 a-c$ (Figure 4). Thanks to this manuscript, then, it is possible to conclude that Zágon did indeed transfer to his own scores the corrections that Debussy had made in the five other songs. Be this as it may, two months later, on 23 March 1911, the cycle received its first performance in the concert hall of Budapest's Royal Hotel on a vocal recital given by the Hungarian soprano Rózsi Marschalkó. The program featured, along with the Zágon, a work by Imre Balabán, and songs by Schubert, Schumann, Brahms, and Rubinstein. On the following day, the critic for the $\mathrm{Bu}$ dapesti Hirlap spoke in his review of influence, which he believed was nefarious, that Debussy had exercised upon Zágon:

Three students from the National Academy of Music, Géza Zágon, Dezső Róna, and Imre Balabán, ${ }^{55}$ gave a vocal recital in the concert hall of the Royal Hotel, with the participation of the soprano Rózsi Marsalkó [sic, for Marschalkó]. The program featured primarily the ultramodern works of Zágon and Balabán. Of Zágon, we heard a cycle of six songs, Pierrot lunaire; of Balabán, a song entitled Szegeden. It is really quite an astonishing experience to learn that a certain strain of the French style that claims to represent the modern school initiated at the Academy of Music by Béla Bartók and Zoltán Kodályi [sic], has already begun to attract some students. To be perfectly honest, we find ourselves thoroughly unable to understand the compositions of Zágon, nor are we really able to take them seriously, these, and all the others, including his works for piano, which seem to us to be nothing more than slavish imitations 
Figure 4 Zágon, Pierrot lunaire, "Messe rouge,” fol. 2v, mm. 22-33 (H-Bn, Ms. Mus. 938) (With kind permission of the National Széchényi Library, Budapest)

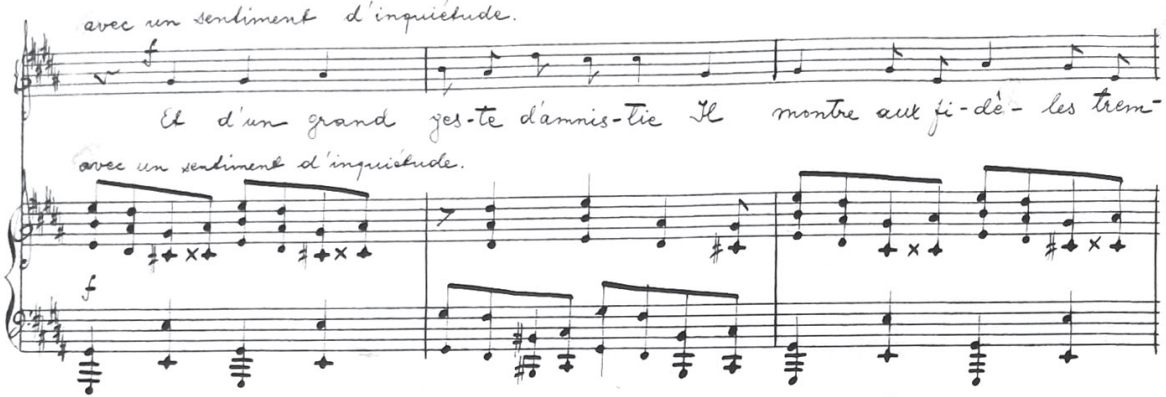

blants twew shingendo
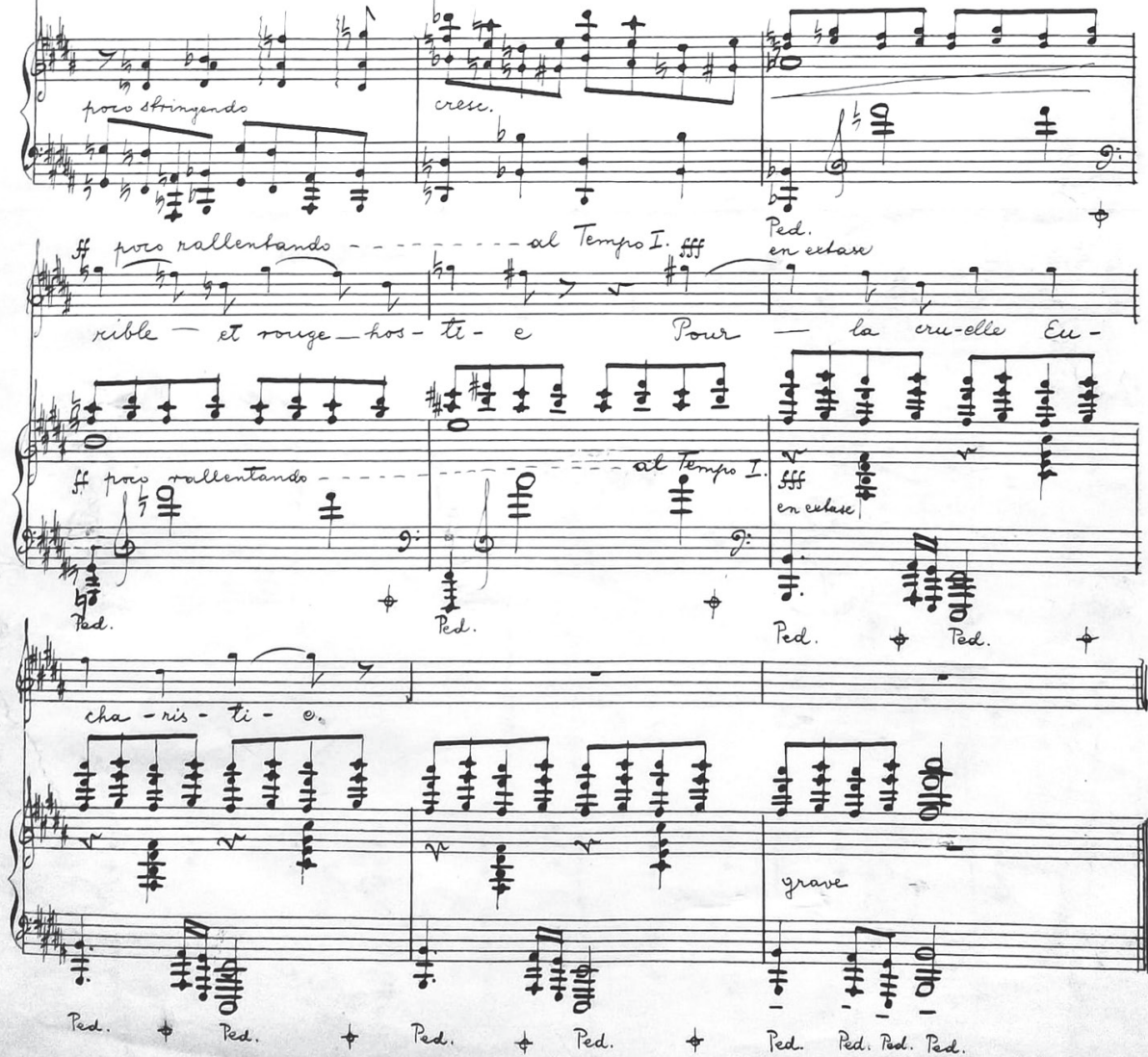
of Debussy, among others ... We did much appreciated the pianistic talents of Zágon: as a performer, he is sincerely deserving of high praise. ${ }^{56}$

The second performance of Zágon's Pierrot lunaire took place in Paris, at the Société Musicale Indépendante, on 17 December 1913, on a varied program that included works by C. P. Simon, ${ }^{57}$ A. Veuve, Louis Aubert, and Louis Dumas. The solo singer was supposed to be Hilda Roosevelt, but in the end she was replaced by Madeleine Bonnard, ${ }^{58}$ as we learn from a piece on 15 December by the influential critic Émile Vuillermoz, an ardent supporter of Zágon's, who announced in Comoedia that

\begin{abstract}
Mademoiselle Madeleine Bonnard, a performer very dear to modern composers ..., will give us the exclusive performance of Pierrot lunaire by Vilmos Géza Zágon, a work both unusual and attractive that comes to us from Hungary, that antedates the pieces by Schoenberg which carry the same title, and that will be heard for the first time in France.
\end{abstract}

The mention of Schoenberg's Pierrot lunaire, the first full performance of which would take place in Paris some nine years later, on 16 January 1922, at the Wiéner Concerts, with Marya Freund ${ }^{59}$ as soloist, is not surprising. Ravel and Schmitt had already thought, in 1913, about having Schoenberg's melodrama performed at the Société Musicale Indépendante, of which it happens that Vuillermoz was a founding member. ${ }^{60}$ In his review, published in Comodia on 22 December 1913, Vuillermoz wrote favorably of the reaction to Zágon's Pierrot lunaire:

56. Budapesti Hírlap, 24 March 1911, 13.

57. The female composer Cécile-Paul Simon (?-1970), the mother of the female composer Claude Arrieu (1903-1990).

58. It is Alfredo Casella who had found this singer, as Hélène Kahn-Casella wrote to Zágon on 13 December 1913: "Monsieur, My husband, desirous of keeping your work on the program, has found for you a singer whose name you surely must know, Mademoiselle Bonnard. She is very interested in your music and would be very happy to be your interpreter. Her address is 47 , rue $\mathrm{S}^{\mathrm{t}}$ Georges, Téléph Central 61,49. Very truly yours, H. Casella. Please request invitations from M. Rey" (H-Bn, Département des Manuscrits, Fond XII/171).

59. See Marie-Claire Mussat, "La réception de Schönberg en France avant la Seconde Guerre mondiale," Revue de musicologie 87/1 (2001), 153-154.

60. In a letter to Igor Stravinsky of 21 January 1913, Florent Schmitt writes that the coordinating committee of the S.M.I. has decided to give Schoenberg's Pierrot lunaire along with Bartók's First String Quartet (see Maurice Ravel, L'Intégrale Correspondance (1895-1937), écrits et entretiens, ed. Manuel Cornejo [Paris: Le Passeur, 2018], 315). At the beginning of April, Ravel described, in the postscript of his letter to Hélène Kahn-Casella of 2 April 1913, the "fabulous project of a scandalous concert" for the consideration of the coordinating committee of the S.M.I. that would include Schoenberg's Pierrot lunaire, Stravinsky's Mélodies japonaises, and his own Poèmes de Mallarmé. Zágon mentioned this project in a letter to Béla Bartók of 26 April 1913: "On the other hand, the members of the coordinating committee did not even look at my Pierrot lunaire, because they already had a contract with Schoenberg for the performance of his Pierrot lunaire (a melodrama, translated into German). But mine is a work of a completely different sort and was written well before his. But the committee believes that it cannot program two works that carry the same title (Denijs Dille, "Briefe an Bartók," 21, 23). It is not known why Schoenberg's Pierrot lunaire was eventually not given by the S.M.I. 
And Mademoiselle Madeleine Bonnard, the young singer whose devotion [to her art] is equal to her continually developing talents, a consummate musician who manages at once to ravish the subscribers to the Bach Society and to thrill the subscribers to the S.M.I., gave of the celebrated Pierrot lunaire by Vilmos Géza Zágon a profoundly musical and extremely intelligent performance. These remarkably lively and original songs, by one of the most brilliant composers of the young Hungarian school, are marked by refined impressionism and written in a highly seductive style. Zágon has translated the puppet-show charm [le charme bergamasque] of Albert Giraud's visions with great sensitivity and exceedingly flexible elegance. His work, a revelation, met with an impassioned ovation. The audience at the S.M.I. has made great progress since the time of Kodály! ${ }^{61}$

Laurent Ceilier, in Le Monde musicale, remarked upon the malicious wit with which Zágon had "translated the meandering and herky-jerky rhythms of his Pierrot lunaire." He continued: "[Zágon] offered up the amusing spirit of these works, six songs each of which is interesting, strange, and lovely, with great unity of purpose"; and added that "L'Escalier" is "one of the best." 62 Jean Poueigh, in La Revue musicale S.I.M., wrote that "the six songs of M. Vilmos Géza Zágon are of superior quality. Although not entirely original, they nonetheless reflect musical instincts that are quite delicate and seductive." ${ }^{63}$ Léon Vallas, in $\mathrm{La} R e$ vue française de musique, observed of the performance that Mademoiselle Bonnard's voice was "as uncertain as it was pretty." "How is it possible to judge these charming pieces, these futuristically tinted melodies, when they are sung without expression, and out of tune?" ${ }^{64} \mathrm{Had}$ Debussy not at the time been on a concert tour in Russia, he would of course have attended the concert. Would this have meant that he was an admirer? It is a difficult matter to measure the nature of Debussy's relationship with Zágon at the time of the latter's stay in Paris in 1912. Nor, unfortunately, do we have any recollections from the Hungarian composer himself concerning his meeting with Debussy, because Zágon died prematurely, only a few years later. We do, however, have a letter that Emma Debussy sent to Zágon, on 22 March 1914, asking that he postpone his meeting with her husband until the following Monday (presumably the $30^{\text {th }}$ ) because he was suffering from the grip, something that proves that the two musicians did indeed continue to see one

61. Comødia, 22 December 1913. Vuillermoz alludes to the more than furious reception that met the performance of Kodály's Six Pièces pour piano (Zongoramuzsika) at the S.M.I. concert of 20 April 1910. See Michel Duchesneau, L'Avant-garde musicale, 73.

62. Laurent Ceillier, “S.M.I.," Le Monde musical 25/24 (30 December 1913), 364.

63. Revue musicale S.I.M. 10/1 (January 1914), 8.

64. Revue française de musique 12/6 (10 January 1914), 237. 
another. And we do know that there once existed a photograph of Debussy (which has not yet surfaced), which the French composer dedicated to Zágon. ${ }^{65}$

$$
* * *
$$

I recognize, by way of conclusion, that some readers might well believe that Debussy's corrections of Zágon's Pierrot lunaire were in fact minimal. Perhaps. They nonetheless provide evidence of his close and attentive reading of the score. And they demonstrate his highly sensitive awareness of the importance of the prosodic accents of a poetic text that has been understood and internalized. We see here, then, and not for the first time, Debussy's attentiveness to poetic forms and to the "music" of poetry. We also see a side of the composer's artistic personality that is not always on view: his openness to the younger generation, and his willingness to offer assistance to one of its number. Edgard Varèse, who made Debussy's acquaintance shortly before Zágon did, reported in an interview with Louise Hirbour: "When I met him for the first time, he was at least forty years old, while I was barely twenty. But he always treated me simply, as a friend, with no condescension whatsoever." ${ }^{66}$ This is precisely the way we believe Debussy treated Zágon, who may in fact have introduced Debussy to some of the works of Bartók and Kodály. And whose interest in Albert Giraud's Pierrot lunaire may have reminded the French composer of the tantalizing aromas of his own youth, when, as an avid reader of the new books and magazines, he was readily fascinated by the latest poetic and literary movements. It is quite likely that, as a passionate bibliophile, Debussy possessed a copy of the 1884 Lemerre edition of Pierrot lunaire, or, if not that one, perhaps the Fischbacher edition of 1898, as André Schaeffner perceptively suspected in his 1953 article on "Variations Schoenberg," whose original title was "Pourquoi Debussy n'a-t-il pas composé Pierrot lunaire?" - "Why did Debussy not compose Pierrot lunaire?" ${ }^{67}$ And even if Schaeffner's criticism of the form of Giraud's collection is rather harsh - "[it is] all too often prosaic, and, in the end, mediocre" 68 - he does express agreement with those who believe that Debussy's affection for the term "bergamasque" - whether it be the title of the Suite for piano of 1890, published in 1905, or the ballet scenario of 1909, Masques et Bergamasques, prepared for Sergei Diaghilev - was inspired not by a line from Verlaine's Clair de lune ("Que vont charmant masques et bergamasques") but rather by the Rondels bergamasques of Giraud's Pierrot lunaire.

65. The picture is mentioned in Zágon's papers, purchased by the Széchényi National Library in 1942. See Boglárka Illyés, "L’ambassadeur parisien," 259, n. 23.

66. Edgar Varèse, Écrits, ed. Louise Hirbour (Paris: Christian Bourgois), 1983, 166.

67. André Schaeffner, Essais de musicologie et autres fantaisies (Paris: Le Sycomore, 1980), 347-371; reprinted in Pierre Boulez, André Schaeffner, Correspondance 1954-1970, ed. Rosângela Pereira de Tugny (Paris: Fayard, 1998), 162-209.

68. Schaeffner, Essais, 350-354 (Correspondance, 165). 
What is more, Schaeffner points to the influence of Giraud's collection on certain poems by Jules Laforgue ${ }^{69}$ one of the writers whom Debussy cherished the most, even though he did not set his poetry to music. To which claim we add that Debussy had, as early as 1882, given in to the charms of the Pierrots in vogue that Jean de Palacio had traced in his book Pierrot fin-de-siècle. ${ }^{70} \mathrm{He}$ had set several of the poems in Théodore de Banville's Cariatides, among them "Pierrot" and "Sérénade," in which Columbine appears. Although they are not rondels, these two poems are both very strictly structured as dizains in the style of Clément Marot. ${ }^{71}$ Finally, Debussy was especially fond of the rondels of Charles d'Orléans: $:^{72}$ he set two of these for voice and piano in 1904, and three for chorus in 1909. ${ }^{73}$ These preferences may further explain why, at the end of 1910, Debussy seems to have been happy to look over carefully the new work, Pierrot lunaire, by the youthful Hungarian composer Géza Vilmos Zágon.

(Translated by Peter Bloom)

Appendix 1

Claude Debussy

by Géza Vilmos Zágon

(translated from the French by Csilla Pethö-Vernet)

A name that has become a symbol. The reunited concepts of novelty, liberty, and beauty, are now designated by the technical term of "Debussysme." But only for a limited number of persons. For the music of Debussy faces the same fate as all artistic phenomena that reveal truly new values; it is music that must make its way through a thicket cluttered with prejudice before allowing us to perceive and understand its heretofore unknown splendors; it is music that must do battle in order

69. Schaeffner, Essais, 349 (Correspondance, 166-170). Jules Laforgue also brought Pierrot to life in various ways. In 1882 he wrote a pantomime entitled "Pierrot fumiste," which was published for the first time in the Entretiens politiques et littéraires of June 1892. Debussy was a reader of this journal, and published in the issue of December 1892 the free-verse poems of his own first Proses lyriques. Furthermore, some of the poems of Laforgue's Complaintes (Paris: Vanier, 1885) evoke the personage of Pierrot ("Complainte de Lord Pierrot," "Autre complainte de Lord Pierrot," "Complainte des noces de Pierrot"). Pierrot also reappears in Laforgue's L'Imitation de Notre-Dame la Lune (Paris, Vanier, 1886), with a section of five poems entitled Pierrots followed by two others, Pierrots, and Locution des Pierrots, containing sixteen poems.

70. Jean de Palacio, Pierrot fin-de-siècle (Paris: Séguier, 1990).

71. That is to say ten lines of ten syllables with a particular rhyme scheme that is most succinctly expressed as: ABABBCCDCD.

72. In 1882, Debussy also set Banville's Triolet à Philis selected from the collection Les Cariatides. Entitled "Zéphyr" by Debussy, this song is in the form of an eight-line rondel with the first line repeated as the fourth, and the first two lines repeated as the seventh and eighth.

73. The first ("Dieu ! qu'il la fait bon regarder !") and the third ("Yver, vous n'estes qu'un villain") were composed in April 1898 for the amateur chorale of the Fontaine family. 
to achieve victory. It must do battle against a kind of narrow-minded conservatism that defines artistic duty as religiously respecting preestablished systems and mechanically acceding to preordained formulas, and finding satisfaction in both; a conservatism that is happy to ban as anarchical, unnatural, or extra-artistic, anything that is unclassifiable in current terminology, anything that requires for understanding and appreciation a point of view and a vision different from prevailing norms; a conservatism that, in so doing, forcefully requires adherence to its own perspectives and its own convictions, which are held to be the only perspectives and the only convictions that are legitimate.

Now, surely there are certain grand and absolute principles that remain eternally viable, but these have to be subjected to innumerably varied intuitions, combinations, and developments, without jeopardizing the underlying, unifying elements. The fact that these variations are designated by the words "freedom" and "novelty" has no impact on the interior content or underlying aesthetic of the work of art. That fact concerns solely its exterior form. The work of art, that which is nothing more or less than the ineluctable manifestation of a true intuition, will always be "free" and "new," as are the works of Beethoven, for example, even today. There was a time when the "Eroica" was tarred with the label of "monstrous"; when its Scherzo was considered an "absurdity." That same Scherzo soon became pioneer of an entirely new genre, and remains to this day exemplary of the form. Who does not know the charming anecdote regarding the slap administered by the composer apropos of the "Eroica"? Mentioning it, we think with a knowing smile of those earlier, innocent times, but that smile becomes unjustified when we realize how far away we are from the era in which Beethoven's great works finally found acceptance among the larger public. At the present time, the larger public remains ignorant of the piano sonatas and the chamber music of the third and last period of his creative life. After a performance of one of those magnificent late works, one often hears remarks such as "it is as though it wasn't by Beethoven!" To mention only several late works in particular, the "Dankgebet [i. e., the Heiliger Dankgesang]" of the great Quartet in A Minor [op. 132], or any one of the movements of the Sonata in C Major for Cello and Piano (op. 102), where we hear, via physical sound-waves floating through the air, utterly beautiful abstractions - these works, for many people, and for many years to come, will remain terra incognita.

Probably, at some future time, it will be we, ourselves, who will provoke those knowing smiles, because there are now and there will always be among us persons who are so deeply shocked by parallel fifths, or by what sounds at first like a bizarre harmonic combination, that their capacity for judgement becomes totally paralyzed; they take these details for the essence, but in fact they miss the whole: they fail to see the forest because of the trees.

Of course there are some unique individuals obviously capable of recognizing essential truths, even when they are utterly distant from or opposite to their own convictions. Alfred Bruneau is such an exception; he is a great defender of that 
joie de vivre, that freedom, and light, and truth, that he has created, with Zola, in his four glorious operas, Le Rêve, L'Attaque du moulin, Messidor, and L'Ouragan, etc. which all set in relief the supreme value of energy and life. The same Alfred Bruneau, beyond merely recognizing them, appreciates to the highest degree the new, art-enriching values discovered by Debussy, despite the fact that the art of Debussy is diametrically opposed to his own. Debussy is totally removed from everything that is stamped with the reality of daily life; he is irresistibly attracted to subjects that are fantastical and difficult to perceive. Regarding nature, he is not interested in things that natural phenomena render available for everyone to see; he is rather interested in things that hide behind those natural phenomena, by things that one cannot fully grasp, by things about which one has only a very vague presentiment. He avoids the light of day. The world in which he feels most comfortable is that of the twilight, and of the night. Consequently, most of his works are dominated by a certain mystery, a mystery often mixed with melancholy, but never deteriorated into sentimentalism.

Naturally, in order to arrive at a mature artistic concept and highly advanced musical language, Debussy had to traverse a period of development. He studied at the Paris Conservatoire, where he was a pupil of [Ernest] Guiraud. In 1884, that is at age twenty-two (he was born on 22 August 1862, in Saint-Germain-en-Laye), he won the Prix de Rome with a cantata entitled L'Enfant prodigue. On returning from his sojourn in Italy, the source of many enriching impressions, he was more and more drawn to the works of the symbolist poets, and to attempting to translate their ideas into music. He was inspired by Verlaine, Baudelaire, Mallarmé, and Maeterlinck $;{ }^{74}$ many of his most remarkable works are due to their motivation.

At the same time, the impressionism of the French painters (whose most eminent representatives are Courbet, Monet, Manet, Pissar[r]o, Renoir, Gauguin, etc.) arrived at its apogee and began to conquer the world. The impressionists find their inspiration in the open air; they realize that it is the impact of light, as it spreads through the atmosphere, that is the unifying factor among so many different patches of color, which, under the influence of the vibrations of the light of the sun, sparkle over innumerably new and never before seen pictorial nuances. The prodigious acceptance of impressionism may perhaps be explained by japonisme. For the impressionists early on recognized the exceptional values of Japanese art, and, in particular, the values of Japanese engravings. The Japanese accentuate the most characteristic features of objects and neglect those that are merely accessory. In doing so, they bring heterogeneous elements into a unity of a higher quality. Rather than viewing their themes, and the aspects of their subjects, in a generalized manner, they rather focus upon them as merely fleeting apparitions, and, still under the impression of the moment and thanks to highly selective colors, they

74. The original text has "Maeterlinek."

Studia Musicologica 59, 2018 
thereby increase the intensity of the whole. After having understood these basic principles, the impressionists determined to adopt them.

In Debussy's early works, we can easily hear the parentage of the music of Bizet and Delibes, especially from the points of view of harmony and rhythm. But this parentage becomes less and less evident, and the real Debussy, who is now a completely isolated figure, comes to occupy a place that is entirely unique. One can try to liken his work to that of a César Franck or a [Modest] Mussorgsky, but such likenesses are essentially illusory. In the music of César Franck, one finds new harmonic progressions as well as certain decorative formulas, for example triplet figures, which Debussy also employs in his own musical style. The relationship to Mussorgsky is more important: he is the only composer of the era preceding that of Debussy whose music - and most notably his songs - conveys similar impressions, although they are far less intense than those which later become omnipresent in Debussy.

The flowering and the truths of impressionism exerted on Debussy such a tremendous impact that he became more and more convinced of that fact that only this artistic movement, with its new possibilities, could foster and advance the art of music. He also set down his principles in writing, and to this day he has remained faithful to them consistently.

All of Debussy's works are impregnated with an intense and all-encompassing atmosphere, out of which there develops - as though coming into view from behind a veil - a panoply of short motifs, splashes of color, sometimes chiseled, sometimes fluid, sometimes the combination of these two; only in exceptional cases can we speak of anything like thematic development in the traditional sense of the term. Atmosphere is the principal element of his music. It is as indispensable as the effects of light of the impressionist paintings. His so-called program music is, in reality, a music of impressions. From this point of view, as from all points of view, he differs quintessentially from Richard Strauss. Strauss's effects are almost always devised in order to express something that is so to speak physically perceptible, or the continuous actions of his program, even in the most abstract cases. Strauss attaches himself to the words, submerges himself beneath the details without considering the whole. As a result, the variously heterogeneous elements of his music stand alongside one another, but rather fail to bond. Debussy's aim, on the other hand, is never to make of his music the interpreter of some sort of program; he wishes simply to reflect and to communicate the impressions that are inherent in the program. That his music, despite everything, often leads to absolutely perfect physical perception is the result of his ultimate virtuoso technique. Nevertheless, such realism is never at the heart of his enterprise; its role, in the end, is decorative. Whatever the program might be that serves as the basis for his writing, the end result will always be a homogeneous ensemble of pure aesthetic abstraction, in which one will find throughout an acceptance of ineluctable choices, and a rejection of elements that are unimportant and superfluous. 
In the expression of his moods, Debussy's harmonic system plays an overmastering role. This system is entirely personal, it is different from everything else, and, precisely for this reason, it is gently tainted by affectation, something however that does not in the least bit diminish its value, for, in the final analysis, one may find in the works of all the great composers a certain degree of affectation. Debussy does not take into account the rules of harmony in the classical sense of the word. In his music, what is in control is a freedom that is absolute, a freedom, however, that is never provocative of disorder, a freedom that is always strictly governed by logic and aesthetics. Indeed, Debussy has created what one might wish officially to designate as the harmony of freedom. He has a predilection for hollow fifths just as for chords without thirds, especially at the beginnings and endings of his works. He is perfectly content to make use of parallel chords in root position, to have the inner intervals of the chords remain the same, to employ parallel octaves and parallel fifths. He treats different kinds of chords in the same way, especially seventh-chords and ninth-chords. In his music we often find eleventh-chords and even thirteenth-chords, which are identical to the so-called "Doppel" and "dreifacher Klang" in the theories of Georg Capellen: these result from the simultaneous appearance of two or even three different chords. Into his chords, he often introduces one or several tones in the harmonic series which are farther away from the root than is traditional, such as the ninth, the eleventh, and the thirteenth. These tones create dissonances of the major and minor second, dissonances which are not always resolved; they are treated freely, by a melodic leap that creates a newly consonant interval, or, again, by another dissonant interval. Nonetheless, these dissonances never sound harsh to the ear; when they are resolved, their apparent severity serves only to heighten the warmth and sweetness of the resolution. What is more, Debussy sometimes uses dissonances as consonances; in his hands, dissonance becomes capable of suggesting closure and conclusion, as in his piano piece entitled Pagodes.

Another characteristic aspect of Debussy's music is the frequent use in it of the ecclesiastical modes, in particular the Lydian and Dorian modes. A number of earlier composers used and exploited the rejuvenating force of the modes for their contemporary music. In the late works of Beethoven, for example, one can find magnificent examples of their use: they are there as indications of the new paths to be followed, gestures made by a genius who anticipated the fulfillment of almost all of the possibilities that are inherent in the art of music itself. They became essential elements in the music of Brahms, who learned of their importance thanks to Palestrina. Without the modes, we would never have been able to take delight, for example, in the miracles of the slow movement of Brahms's Symphony in E Minor.

Debussy broke away from the chromaticism of the nineteenth century; he refused, that is, to employ chromaticism, from a harmonic point of view, as a generator of successive modulations, for he realized that that would not offer any new possibilities for the evolution of his art. One can even find in his music a 
tendency to avoid leading-tones, something that is of course a natural and logical consequence of regularly employing the ecclesiastical modes. With Wagner, and with Tristan in particular, chromaticism attained its zenith; after that, a decline became simply inevitable. All efforts directly to continue this means of expression are doomed to fail, or, in a best-case scenario, to lead to nothing more than feeble copies, with no real value and with no real future, such as we find in the impotent chromaticism of Strauss and Reger. German music is suffocating under the enormous weight of the ghost of Wagner. Only by entirely emancipating and freeing itself from the influence of Wagner can the art of music find fresh liberty and blossom anew. But it is highly unlikely that such emancipation will arrive any time soon. Indeed, the current state of musical affairs suggests precisely the opposite.

It is important to speak here of a widespread notion that in fact represents a grand misconception, a misconception that must be corrected in the strongest and most energetic terms possible. That misunderstanding has it that Debussy's harmonic system is based on the whole-tone scale. Now, it is undeniable that this represents a characteristic element of his music, but its role is by most people misunderstood. You can very easily obtain a whole-tone scale if you create a diatonic passage beneath an altered chord, and especially an altered dominant-seventh chord (for example, $G, F, D$-sharp, $B$ ): consequently, the whole-tone scale, in our tonal system, is nothing more than the transference of the principle of chordal alternation from the realm of harmony to the realm of melody. The whole-tone scale is in no way the invention or the exclusive privilege of Debussy. But it is he who fully recognized the importance of this scale, and who used it on regular occasion. It never serves as the foundation for his music; it rather plays a transitory role, as the means of expression which is most adapted and essential to a grand crescendo or grand diminuendo in the realm of dynamics or of overall structure. In the rare cases in which it apparently functions as a point of departure (for example in the piano piece entitled "Cloches à travers les feuilles"), it functions merely as an introductory phenomenon that prepares for what follows, just as do harmonies at the beginning of a piece that are foreign to the main tonality, something often used by the great composers.

The whole-tone scale - a scale that is central to Japanese music and compatible with Japanese instruments - cannot be integrated into our tonal system as an independent scale. The most obvious proof of this statement is the fact that one cannot arrive at the note one octave higher from the note at the point of departure without effectuating an enharmonic change. For example: $G, A, B, C$-sharp=D-flat, $E$-flat, $F, G$. Without the enharmonic change, we would have $G, A, B, C$-sharp, D-sharp, E-sharp, F-double-sharp.

The imitators who use the whole-tone scale, for no particular reason, as an independent element of harmony or melody - without understanding its true nature, convinced of the fact that it will satisfy the exigencies of the modern style - should be seen as mere dilettantes, engaged in amateur experimentation. 
The music of Debussy is homophonic, which means, in his case, that all of its constituent elements converge into a unity of the highest order. In his music, we cannot speak of counterpoint in the old-fashioned sense of the word: he presents motifs of the same value and the same importance simultaneously in a way that is free and that does not take into account their rapport with others, not in order to accentuate their eventual differences, but rather in order to unite them into a higher musical substance, in order to allow preexistent expressive entities to create a new and all-embracing impression.

Because of the impressionistic nature of his music, we rarely find in it structures in the traditional sense of the word. In his shortest pieces, we can detect twopart or three-part forms resulting from the recurrence of certain motifs or certain interdependent and analogous passages. It is furthermore admirable that, even in his most complex works, where no such articulations are present, the proportions are so perfect that the whole seems to be the result of an inner necessity, of a pure and absolute aesthetic principle. Debussy always puts forth the tonality in a strong and deliberate fashion, and he remains in contact with it even in the tonally most remotely distant passages.

To those who, even after hearing this explanation, still remain perplexed by the work of Debussy, I should like to propose an experiment: go and look at a painting by Picasso (not to be confused with Pissar[r]o). The angularity of his figures represents not a malformation but rather a kind of immobilization - an immobilization with the expressive value of a split second in time, a momentary reflection of an emotion, an emotion that is so inaccessible and so secreted that it cannot be revealed by mere externalized means. We have suspected its existence, but we have not found a trace of it on the faces, for it has disappeared before we have been able to catch it. And now it is suddenly there, realized before our eyes, the very incarnation of the sadness composed of a material that for us is unknown and impossible to define: the split second in time, conserved for all eternity.

Most of the works by Debussy that seem mysterious are analogous to this artistic process: they are representations of an inexpressible, subconscious atmosphere. Music, which as an artform is far more ineffable than painting, is well suited to this kind of expressiveness. It is natural that this music appears malformed to the majority of the public and that it appears angular only to the minority, who understand that such angularity is far more fascinating than some empty roundness.

Debussy marches to the beat of his own drum down a path that leads in a direction different from that of any other composer. At the moment, it is simply impossible to know with certitude where he will go. It is not impossible, indeed, it is probable that he has achieved his highest expression in the works he has already composed. Even if that is true, the masterpieces that he has created are sufficiently important such that his name will be forever inscribed on the memorial list of the great figures, what is more, the greatest figures in the history of music. His is one of the most brilliant personalities of the art of music, something that explains why 
no one has ever been able successfully to imitate him. Those who have tried have either soon realized the futility of their efforts, like Ravel, whose extraordinary ability allows us to hope that he will arrive at his goals by means entirely of his own making, or they have fallen on their faces under the weight of his yoke, their remaining force paralyzed, like Roger-Ducasse, who actually deserved a better fate.

It nevertheless goes without saying that the artistic road traced by Debussy simply cannot be circumvented. In all areas, he has created values that have become nearly universal and that will have been taken into consideration by all composers worthy of the name. He who will be capable of creating something new, while integrating into his music the values of the work of Debussy, will have to develop an artistic personality just as strong as his. That person's art will of necessity be significantly different from Debussy's.

Whatever the force for which he has composed, whether it be the orchestra, the piano, or the human voice, Debussy has treated each in his own, unique manner, in a way practiced by no other composer. He has managed to exploit the most hidden qualities of the instruments and voices and thus to attain his desired goal. His way of working with the orchestra, the piano, or the voice, has in and of itself been an important factor in creating the atmosphere of his music. He has exulted in each of these domains in his own private way: it is impossible to establish the relative value of his works in terms of the forces for which they are written, or to attribute greater value to works for certain forces than to works for others.

Debussy now finds greater and greater acceptance and understanding in Germany, a country that, most often, has hardly demonstrated objectivity towards the French. Be this as it may, his success in Germany is surely more important than his success in England and in the United States where, outside of France, his music is most well-known. This may perhaps be explained by the nature of the English race, which, being extremely superficial in its musical judgments, always salutes with great enthusiasm everything that piques its curiosity by novelty alone. Obviously, at one time or another, the creation of novelty is something that is possible even for some of the lesser lights of music. On this occasion, fortunately for the English, their excitement has been created by a Debussy.

One phenomenon is interesting to point out: the Parisian première of a work by Debussy is always, to this day, a scene of a confrontation of opposite opinions, a scene never lacking in hecklers, who are nonetheless always beaten back by the composer's partisans, who are usually present in greater numbers than theirs. Debussy has no enemies in the strict sense of the word. Because the French are aware of the importance that his music has had for them, not only from the point of view of the art, but from the point of view of the nation. Debussy's music, emancipated as it is from all foreign influence, has proven that it is possible for French genius to develop and to advance on the basis of its own merits.

Like his art, independent and solitary, Debussy himself has until now maintained and protected his personal freedom, which is still intact. He does not be- 
long to the Conservatoire, which, if he did, would signal a kind of submission to, or at least an acceptance of, certain established artistic principles. The evidence suggests that he can also not be a member of the Schola Cantorum, directed by another eminent figure on the French musical scene, Vincent d'Indy.

We await his concert with a tremendous anticipation that is only escalated by the importance of his exceptional place in the world of music. We shall have occasion to hear Debussy as pianist. What is more, the magic of his presence in person, and the authenticity that we are guaranteed to hear and feel in the works that he will play, promise a musical experience of the highest quality.

\section{Laudation of the works to be performed by Géza Vilmos Zágon (translated from the French of Csilla Pethö-Vernet)}

Debussy dedicated the Children's Corner to his daughter. The figures presented to the imagination of the child - who attributes to them an important role - appear in these pieces. Through the arpeggios of Doctor Gradus ad Parnassum there blossom forth melodic lines full of sweetness. The somewhat exaggerated realism of Jimbo's Lullaby ("The Lullaby of the Elephant") rather suffocates the purely musicale values of the piece. The Serenade for the Doll is full of harmonic subtleties. The Snow is Dancing is a veritable miniature work of art, evoking with gripping realism the fluttering of snowflakes, as though by magic, and thus expressing all of the poetry inherent in that impression. It happens that Debussy has used a popular French folksong in this piece. The Little Shepherd develops a particularly lovely pastoral atmosphere. The final piece is Golliwogg's Cakewalk. A golliwogg is nothing else than a devilish little creature, which scares young children: it is the bogeyman, the terrible little demon who haunts children's bedrooms. This piece, to the traditional cakewalk, is what Chopin's waltzes are to the genre of the waltz: it raises the rank of the original dance to the level of high art.

Debussy's Pagodes are suggestive of the exotic ambiance of pagan temples. The listener believes that he hears tiny bells attached to pagan idols and activated by the breeze. Here, we hear everything that is opposite to what corresponds to our own traditions.

Hommage à Rameau begins with a theme played in unison, and then, later, harmonized in variously imaginative ways. The piece is rather like a vibration of a completely static impression, moving forward along a straight line beneath which grand passions seem profoundly to slumber. Towards the middle, the tempo increases and we reach a kind of climax. This is one of Debussy's most beautiful works for the piano.

Jardins sous la pluie (Gardens in the rain) are dominated by one omnipresent motif. At the beginning, we have the impression of the sounds of pizzicato strings: these represent the noise of raindrops. The rain will gradually fall more heavily, to the point of literally inundating the gardens. There follows a calmer section, which suggests nothing more than even finer rain falling from the heavens. A mysterious section passes by that seems to reflect a sad image 
of decline. Then, the principal motif reappears, now as a section of compact triads. The sun breaks through the clouds and inundates by its light the moist vegetation still covered with sparkling drops of water. Nature has been fertilized.

\section{Appendix 2}

\section{[Pierrot lunaire]}

\section{[Géza Vilmos Zágon]}

\section{Salle Pleyel at 9 o'clock. S.M.I.}

The songs of M. Vilmos Géza Zágon are based on the work of the Belgian poet Albert Giraud, and come from his collection entitled Pierrot lunaire. All of the poems here assume the same form, one that is essentially musical: each poem comprises twelve lines grouped into stanzas of four, four, and five lines. The seventh and eighth lines always correspond to the first and second lines; the thirteenth line always corresponds to the first. The poems resemble those of Verlaine's Fêtes galantes in terms of the ideas and emotions that motivate their personages, impassioned "masks" upon whom are reflected tender souls like that of Schumann. At the same time, however, as the author tells us, these are just so many sumptuously painted images that evaporate in the pale blue of one's dreams. The piano is not constrained to a simple accompaniment; it plays a role that is both important and independent.

The first piece, "Théâtre," is a kind of prologue that announces the settings of the events that will place and that presents some of the personages of the "mimodrame." In "Spleen," "Pierrot de Bergame is bored," while the "Chanson de la pluie" spatters rain on the windows. "Messe rouge" has us attend Pierrot's gruesome ceremony in which he holds "up his heart, to the terrified faithful, in his bloody fingers," with the piano concluding in a violent sounding of church bells. "Poussière rose" is imprinted with the civility and the freshness of the morning. "L'Escalier," despite a title that is hardly poetic, is an evocation of Pierrot's devotion to Colombine. In "Départ de Pierrot," the nostalgic Pierrot returns to Bergamo, his homeland.

The first performance of this work was given in Budapest on 23 March 1911. The composition thus antedates the work that carries the same title by M. Arnold Schoenberg, the leader of the young Viennese school. 


\section{Appendix 3}

\section{Claude Debussy to Géza Vilmos Zágon, 22 January 1911}

Cher Monsieur,

Along with this letter you will receive the score of your Pierrot lunaire with the corrections I felt it necessary to make, almost all of which, in fact, concern the prosodic accents.

In particular, I should like to call to your attention to the somewhat forced "tessitura" of "Messe rouge." Do you not think that a voice that would sound well at both the beginning and the ending will be difficult to find? Perhaps it might be wise for you to modify the ending.

The music that describes Pierrot's departure seems to me to be less felicitous than that of the other pieces... To be perfectly honest, it is more lunaire [that is, more wacky] than Pierrot. In the poem, there is a kind of animation, a kind of fantasy, that is simply not found in your music. It seems to me that you ought to attempt to try to find something better, namely, something that would preserve all of Pierrot's moonstruck melancholy while at the same time surrounding it with lighter, more evanescent rhythms.

Given your very real talents as a truly gifted musician, you ought not to be satisfied, in my view, by something that is not entirely polished.

With my compliments, please believe, cher Monsieur, that I am very truly yours,

\section{Claude Debussy}

The letter is written on mourning letterhead.

The envelope carries a departure postmark of 30-1 11; there is no arrival postmark. The address is: "Monsieur Guillaume Zágon / / V. Zoltán-utcza. 11. / à Budapest. / - Autriche-Hongrie -

Autogr.: H-Bn, Fond XII/199. Publ.: Boglárka Illyés, “L'ambassadeur parisien,” 272.

\section{Claude Debussy à Géza Vilmos Zágon / 22 - I/11.}

Cher Monsieur,

vous recevrez en même temps que cette lettre, votre Pierrot Lunaire avec les corrections que j'ai cru devoir y apporter, qui, d'ailleurs, portent presque toutes sur des accents prosodiques.

Plus spécialement, je vous ferais remarquer la «tessiture » un peu forcée de «Messe rouge ». - La voix qui pourrait à la fois sonner au commencement et à la fin me semble difficile à trouver ? Peut-être y aurait-il profit à modifier la fin.

La musique que décrit «le départ de Pierrot» ne me paraît pas aussi heureusement trouvée que dans les autres pièces... Pour tout dire, elle est plus lunaire que Pierrot. Il y a dans 
le poème, un mouvement, une fantaisie que l'on ne retrouve point dans votre musique. Vous devez, il me semble, trouver mieux ; et, tout en conservant cette sorte de mélancolie lunaire, l'entourer de rhytmes plus légers, plus impalpables.

Étant donné vos réelles qualités de musicien vraiment doué, vous ne devez pas, à mon avis, vous contentez d'un à peu près.

Avec mes compliments, croyez, cher Monsieur, à mon meilleur souvenir.

Claude Debussy

Lettre sur papier grand-deuil.

Enveloppe avec cachet postal (départ : 30-1 11 ; pas de cachet d'arrivée) et adresse : Monsieur Guillaume Zágon / V. Zoltán-uteza. 11. / à Budapest. / - Autriche-Hongrie -

Autogr. : H-Bn, Fond XII/199. Publ. : Boglárka Illyés, «L'ambassadeur parisien... », p. 272. 